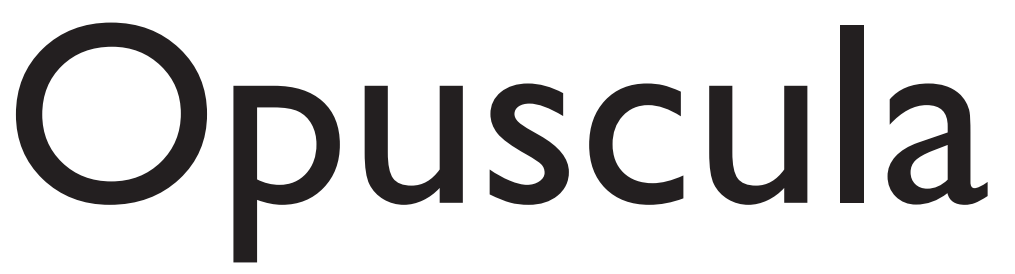

Annual of the Swedish Institutes at Athens and Rome

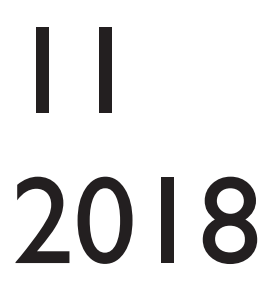

STOCKHOLM 


\section{EDITORIAL COMMITTEE:}

Prof. Gunnel Ekroth, Uppsala, Chairman

Prof. Arne Jönsson, Lund, Vice-chairman

Mrs Kristina Björksten Jersenius, Stockholm, Treasurer

Dr Susanne Berndt, Stockholm, Secretary

Dr David Westberg, Uppsala

Dr Sabrina Norlander-Eliasson, Stockholm

Prof. Peter M. Fischer, Göteborg

Prof. Anne-Marie Leander Touati, Lund

Dr Lena Sjögren, Stockholm

M.Phil. Lewis Webb, Göteborg

Dr Jenny Wallensten, Athens

Dr Kristian Göransson, Rome

\section{EDITOR:}

Dr Julia Habetzeder

Department of Archaeology and Classical Studies

Stockholm University

SE-10691 Stockholm

editor@ecsi.se

\section{SECRETARY'S ADDRESS:}

Department of Archaeology and Classical Studies

Stockholm University

SE-10691 Stockholm

secretary@ecsi.se

\section{DISTRIBUTOR:}

eddy.se $\mathrm{ab}$

Box 1310

SE-621 24 Visby

For general information, see www.ecsi.se

For subscriptions, prices and delivery, see http://ecsi.bokorder.se

Published with the aid of a grant from The Swedish Research Council

The English text was revised by Rebecca Montague, Hindon, Salisbury, UK

Opuscula is a peer reviewed journal. Contributions to Opuscula should be sent to the Secretary of the Editorial Committee before 1 November every year. Contributors are requested to include an abstract summarizing the main points and principal conclusions of their article. For style of references to be adopted, see www.ecsi.se. Books for review should be sent to the Secretary of the Editorial Committee.

ISSN 2000-0898

ISBN 978-91-977799-0-6

(C) Svenska Institutet i Athen and Svenska Institutet i Rom

Printed by Göteborgstryckeriet, Mölndal, Sweden 2018

Cover illustrations from Lindblom et al. in this volume, p. 82. 


\section{Contents}

7 REBECCA WORSHAM, MICHAEL LINDBLOM \& CLAIRE ZIKIDI | Preliminary report of the Malthi Archaeological Project, 2015-2016

29 PETER M. FISCHER \& TERESA BÜRGE | The New Swedish Cyprus Expedition 20 I7: Excavations at Hala Sultan Tekke (The Söderberg Expedition). Preliminary results. With contributions by M.Ausiayevich, B. Placiente Robedizo,V. Barrera Alarcón, L. Recht \& D. Kofel

8I MICHAEL LINDBLOM, GULLÖG NORDQUIST \& HANS MOMMSEN | Two Early Helladic II terracotta rollers from Asine and their glyptic context

97 GINA SALAPATA | Tokens of piety. Inexpensive dedications as functional and symbolic objects

III SIGNE BARFOED | The use of miniature pottery in Archaic-Hellenistic Greek sanctuaries. Considerations on terminology and ritual practice

I27 KATIA MARGARITI | Painting early death. Deceased maidens on funerary vases in the National Archaeological Museum of Athens

I5I SUSANNE BERNDT | The hand gesture and symbols of Sabazios

169 CHRYSANTHOS KANELLOPOULOS \& MANOLIS PETRAKIS | Cella alignment and 4th century BC Doric peripteral temple architecture in Mainland Greece

20I Book reviews

211 Dissertation abstracts 2017-2018 
Licensed to <openaccess@ecsi.se> 


\section{The hand gesture and symbols of Sabazios}

\begin{abstract}
The material evidence left from the cult of Sabazios is meagre, apart from sculpted bronze hands dating to the Roman Empire. The hand is held in a certain pose, the so-called benedictio Latina gesture, and the hand was often covered with depictions of various objects and symbols. The bronze hands were probably attached to staffs and carried around in processions. This practice most likely spread via the channels of the Roman army during the Early Imperial period, but the gesture existed much earlier. The gesture is found on Attic black- and red-figured pottery, and is frequently associated with Hermes in his role as instructor and Psychopompos. From the beginning of the Hellenistic period the gesture was mainly used as an indication of speech, and for knowledge transmitted through speech. There are several examples of how the gesture was used to indicate the knowledge revealed through the initiations of mystery cults. Hermes is closely associated with Sabazios and is represented on the bronze hands, probably because of his role as instructor and Psychopompos; i.e. the position played by the mystagogue in the Sabazian mysteries. The gesture of the hands simply denoted the knowledge acquired through the initiation. The symbols on the hands are often associated with the Underworld, and it is suggested that knowledge acquired in the Sabazian mysteries dealt with life after death and the Underworld.
\end{abstract}

Keywords: Sabazios, cult, hand gesture, benedictio Latina, bronze hand, mystery cult, Hermes, gesture of speech, Roman Empire, Underworld

https://doi.org/10.30549/opathrom-11-08

\section{Introduction}

This study deals with the ancient cult of Sabazios where a specific hand gesture appears to have been a prominent feature: the aim of this article is to examine and analyse this so-called benedictio Latina gesture and its role in the cult. The thumb, index and middle fingers are extended, while the ring and little fingers are folded into the palm. This gesture is preserved on a large number of sculpted bronze hands, which are usually decorated with a large range of depictions of objects. These objects are helpful symbols, which I will also take into consideration when discussing the hand gesture.

\section{General background of the cult}

Sabazios is generally defined as a Phrygian deity both by ancient authors and by modern scholars. ${ }^{1}$ The ancient literary sources often identified him as Dionysos, while in the epigraphic evidence he is usually identified as Zeus. Sabazios is often also connected with other deities, such as Cybele while he is most often accompanied by Hermes/Mercury. ${ }^{2}$ Of importance for this study is that the cult of Sabazios was a mystery cult, i.e. it involved inititation probably with some knowledge or instructions given beforehand. ${ }^{3}$

Sabazios cannot be attested in the literary sources until the end of the 5th century BC, ${ }^{4}$ and even later in the archaeo-

\footnotetext{
${ }^{1}$ Some earlier scholars have, based on some ancient sources, described Sabazios as being of Thracian origin. The earliest ancient sources, however, made a connection with Asia Minor, while a Thracian connection is earliest documented in literary sources of the 1st century BC. For a collection of the ancient sources, see Lane 1985, 46-52. For references to modern studies on Sabazios, see Johnson (1984, 1608-1612) who has collected most of them in a bibliography. For more recent studies of Sabazios, see e.g. Lane 1989, 1-10; Fol 1998; Tassignon 1998; Roller 2001; Takács 2001; Bodinger 2002; Popova 2007 and Roller 2013.

2 A fact noted by several scholars, see e.g. Lane 1989, 13; Tassignon 1998, 193.

3 Lane 1989, 2; Widengren 1961. Inscriptions from Sardis, Pergamon and Ormeleis in Asia Minor further confirm that it was a mystery cult in Asia Minor, see Lane 1985, cat. nos. 27, 31, 43; Roller 2001, p. 7 of 18 unnumbered pages.

${ }^{4}$ Sabazios is mentioned in four different comedies by Aristophanes, dated to between 422 and 411 BC: Ar. Horae frg 566; Vesp. 8-10; Av. 876; Lys. 387f. The contemporary comedian Eupolis (frg 84, ed. Edmonds 1957 ) is probably also making a reference to the cult of Sabazios. A fragment of the comedy Baptai (dated perhaps to 416 or $415 \mathrm{BC}$ ) mentions
} 
logical material, beginning with the Early Hellenistic period. ${ }^{5}$ Iconographically he cannot be identifed with certainty until much later, in Roman Imperial times, when he is depicted as a bearded elder. In Asia Minor Sabazios is in particular well attested in Lydia, as well as Pergamon, from the beginning of the Hellenistic period. The cult appears to have spread quite quickly around the Mediterranean during the following centuries, because, according to Valerius Maximus (1.3.2), worshippers of Sabazios were deported from Rome in 139 BC. Further evidence that the cult had spread throughout the Roman Empire by the Augustan period is a bronze hand, dated to $c .15 \mathrm{BC}$, from the Roman military camp at Dangstetten, in present-day south-west Germany. ${ }^{6}$ The amount of related finds from Pompeii and Herculaneum further confirms that the cult was well established at the time of the eruption of Vesuvius in $\mathrm{AD} 79$ ?

\section{Earlier interpretations of the hand gesture}

Despite a significant amount of research of the Sabazios cult, there are surprisingly few studies dealing with the gesture itself. Most scholars have examined the various symbols on the bronze hands, rather than the gesture itself. However, various interpretations of the gesture's role within the cult have been proposed, such as blessing, healing, providing divine help, protection, expressing the spoken word, denoting divine power, or a divine triad. ${ }^{8}$ The latter theory was rightly dismissed by

the ritual cry "Euai sabai". The same cry is also attested by Demosthenes (De cor. 259-260) in $330 \mathrm{BC}$.

5 The earliest securely dated archaeological evidence is a black-glazed skyphos cup inscribed with the name of Sabazios dated to 325-300 BC (Hannestad et al. 2002, 47, 50, 129, 138-139, 229, cat. nos. B 98, H2, pls. 63,71 ). The drinking cup was found at Panskoye (close to Chersonesos, on the northern shore of the Black Sea), and was probably a dedication to Sabazios. A statue base dated to 342/1 BC (Lane 1985, cat. no. 52) was found in Piraeus apparently at the same spot as a later inscription $(c .100$ BC) recording members of the cult of Sabazios (Lane 1985, cat. no. 51), and it has therefore been suggested to have been connected with Sabazios (Lane 1985, 26). The so-called Droaphernes inscription from Sardis is a 2nd-century AD Roman recarving of one dedication and two religious edicts. The dedication and the religious edicts are separated by a carved leaf, and the mysteries of Sabazios are mentioned in the first edict. The dedication is assigned to the Achaemenid period (probably 4th century $\mathrm{BC}$ ), while the two edicts may well date to a later period as indicated by the leaf. As there is uncertainty about the date of the edict mentioning Sabazios, I have chosen not to include it among the early evidence of Sabazios. For the inscription see Robert 1975, Briant 1998, Dusinberre $2003,118,233$, cat. no. 40 for further references.

${ }^{6}$ Fellmann 1978, 285-286.

7 Vermaseren 1983, cat. nos. 10-19.

8 Blinkenberg $(1904,101-103)$ interpreted the gesture within the Sabazios cult as one of blessing and healing. See also Blinkenberg 1904,
Youssef Hajjar, who himself interpreted the hand as a symbol of divine help and protection. ${ }^{9}$ Sherman E. Johnson suggested that the gesture may have been connected with the recitation of a holy formula, and that the bronze hands possibly were used as cult objects to bless the worshippers. ${ }^{10}$ Isabelle Tassignon discussed the upraised arm, rather than the hand gesture itself, and she interpreted the upraised arm together with the hand as one of dominance or authority. ${ }^{11}$

Hans Peter L'Orange has in my opinion convincingly demonstrated that the gesture in general expressed the spoken word and was a sign of logos during the Roman Empire and Late Antique periods, but the gesture had nothing to do with what was said or taught. ${ }^{12}$ L'Orange, however, did not discuss the gesture in earlier periods or how the symbols on the Sabazios hands may be understood associated with a gesture of speech. It seems that scholars in general also have had diffculties in accepting this interpretation. Martin P. Nilsson, for example, thought that a gesture of speech could not explain all the attributes covering the hands. ${ }^{13}$

Eugene N. Lane, who has written extensively on the Sabazios cult, discussed the various symbols on the hands, but confined himself to describe the gesture as the benedictio Latina and that it originally was an orator's gesture. He did not develop any theories what the gesture may have signifed in the cult, but declared that the field was open to speculation. ${ }^{14}$

It is now my intention to try and demonstrate why a gesture of speech befits the Sabazios hands, by taking earlier evidence and the various attributes into consideration.

123-128 for a more general discussion of the gesture. Eisele (1909$1915,242)$ interpreted the gesture as one of divine help. Oesterley $(1935,140-142)$ suggested that it denoted a divine triad. It is uncertain, however, which three deities Oesterley identified as part of the triad, but plausibly Persephone, Zeus, and Sabazios or Zagreus. The gesture is often described as one of blessing without its significance in the Sabazios cult being developed any further, see e.g. Fellmann 1981, 323, 329 and Roller 2001, 6; 2013, 5988 .

9 Hajjar 1978, 467-470.

10 Johnson 1984, 1595-1596.

11 Tassignon 1998, 197-198.

12 L'Orange 1953, 184-187. Richter (2003) later made a more thorough examination of the gesture in Roman art, and came to the same conclusion (see esp. 142-147). He, however, excluded two material groups from the study, the bronze hands of Sabazios and reliefs of the so-called Dacian/Thracian horsemen (Richter 2003, 4).

${ }^{13} G G R^{2}$ vol. 2,658 , n. 4.

${ }^{14}$ Lane 1980, 13; 1986, 198. 


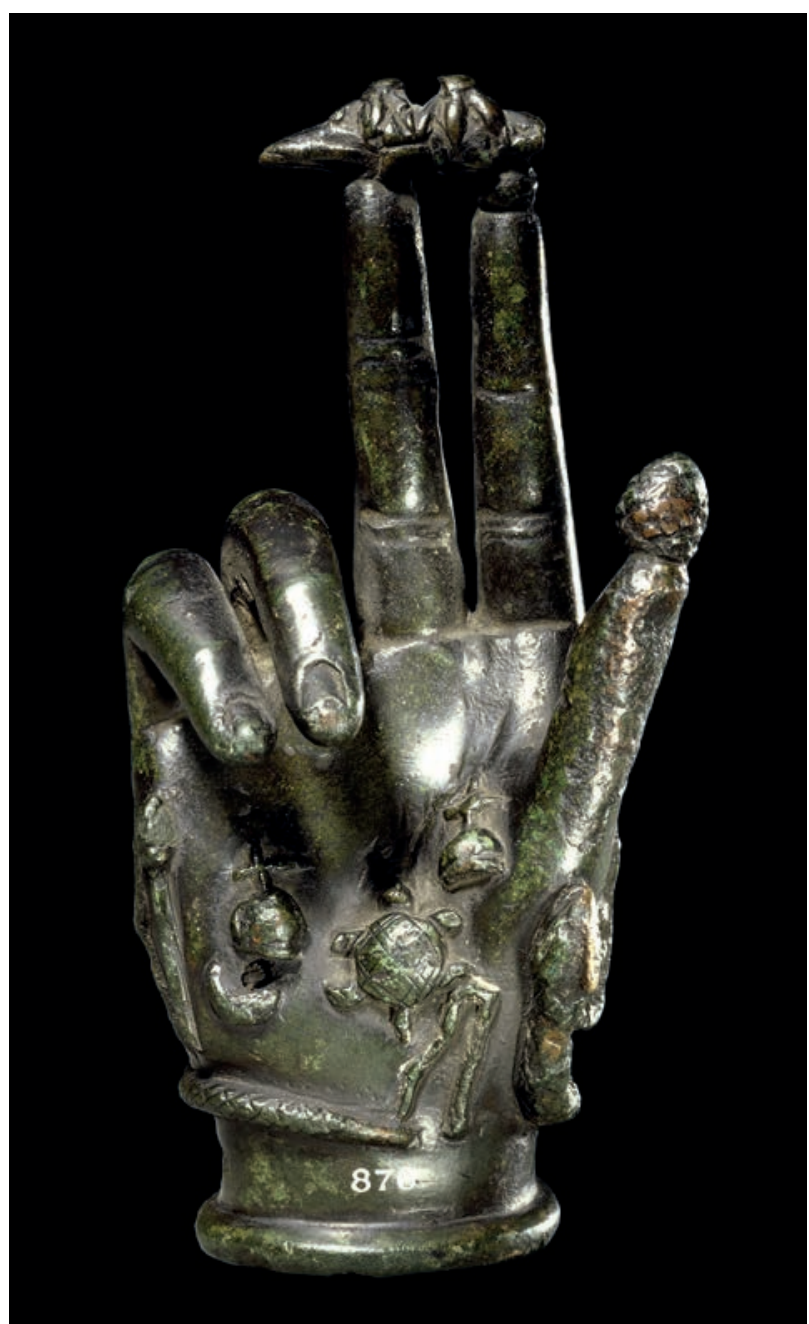

Fig. 1. Bronze hand found at Tournai in Belgium, close to the BelgianFrench border, now in the British Museum, inv. no. 1895, 0621.4. Height c. $15 \mathrm{~cm}$. Photocredits: (C) The Trustees of the British Museum.

\section{The material evidence — the bronze hands}

The main material evidence of the cult are the sculpted hands in bronze, usually at life size or smaller, of which there are around 80 examples, in addition to 14 figurines or busts that were probably once attached to hands. ${ }^{15}$ As well as the hands,

\footnotetext{
15 Vermaseren 1983, cat. nos. 1-18, 25-33, 38, 40-42, 45-55, 57-79, $80-82,84-86,88-96$. The bronze hand with cat. no. 44 in Vermaseren $(1983,19)$ is reportedly a fake. There are also some small bronze figurines or busts presumably of Sabazios, which probably once belonged to bronze hands, see Vermaseren 1983, cat. nos. 19-24, 36-37, 39, 43, 80, 83, 87; von der Osten 1953. There is one hand of terracotta (Vermaseren 1983 , cat. no. 56). In addition to bronze hands there are also a few pins in bone with a hand on top, see below for a discussion. Some of the hands
}

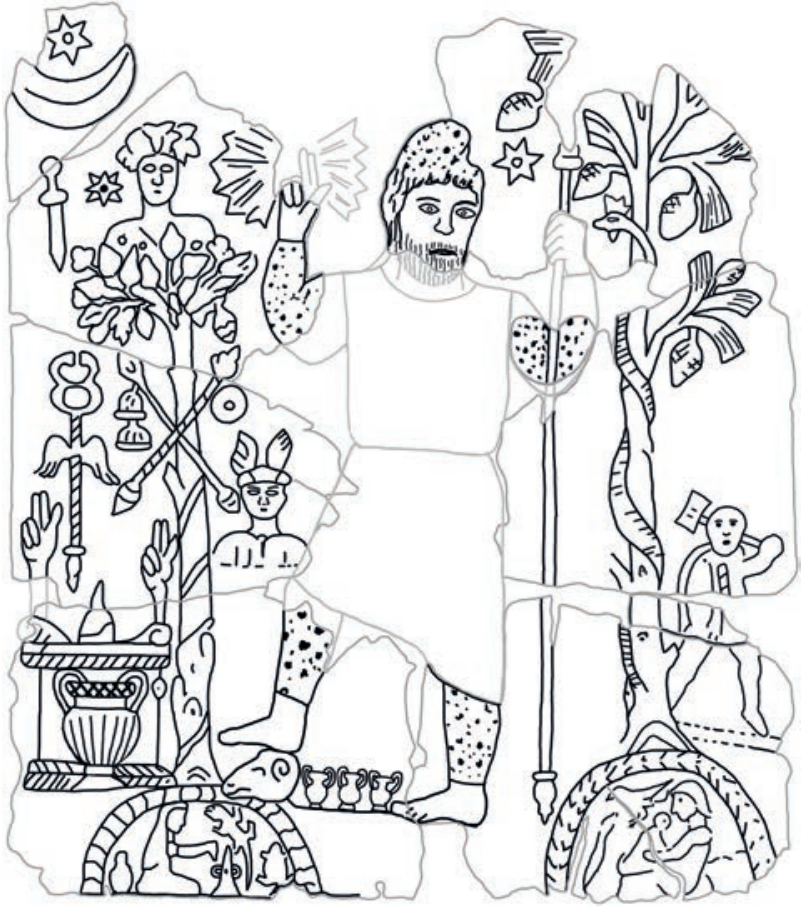

Fig. 2. Bronze plaque from Emporiae, now in Gerona Museum. Drawing by the author after Lane 1985, fig. 85.

there are also some reliefs of the god, but only one preserved statue. ${ }^{16}$ There are also a few terracotta vessels and an altar, which were found in a domestic shrine at Pompeii. ${ }^{17}$

In general it is the right hand, always held in the same gesture, that is depicted. The hand often holds various objects or is decorated with symbols, such as snakes, lizards, frogs, trees and pine cones. (e.g. Fig. 1). The majority of hands have a nail hole at the bottom, because they were apparently once fastened on top of (wooden) sticks. This is also confirmed by images where the god himself is holding such a staff. ${ }^{18}$ In one image from Emporiae (in Spain) two hands are placed on top of an altar or perhaps rather surmounted on sticks placed behind the altar (Fig. 2). Sabazios himself is also often depicted with one hand (usually the right) or both hands making the gesture. ${ }^{19}$ Many of the bronze hands have a small statuette of a seated Sabazios in the palm making the specific gesture

carry a dedication to Sabazios (Vermaseren 1983, cat. nos. 5, 28, 76; Lane 1980, 13).

16 Lane 1985 , cat. no. 77 . The statue is from a sanctuary of the Roman period at Çavdarlı close to Afyon in Turkey.

${ }_{17}$ Vermaseren 1983, cat. nos. 15 bis.

18 See e.g. Lane 1985, cat. nos. 78, 79a, 80, D3. The statue from Çavdarlı (Lane 1985, cat. no. 77) is missing both hands but the left hand is raised as if a staff was being held.

${ }^{19}$ See e.g. Lane 1985, cat. nos. 85-86, 88, D3. 
with one or both hands. ${ }^{20}$ As mentioned above at least some of these hand models were fastened on poles, and plausibly carried around in processions. ${ }^{21}$

Bronze hands that apparently were intended to be fastened on poles were not a phenomenon restricted to the Sabazios cult, as examples are known from other cults, such as Jupiter Dolichenus and Jupiter Heliopolitanus. These bronze hands, like the ones of Sabazios, often have preserved holes at the wrist so they could likewise have been surmounted on top of poles and carried around in processions. Jupiter Dolichenus originated in Doliche (present-day Gaziantep) in south-east Asia Minor and was a popular god among Roman soldiers who spread the cult throughout the Roman Empire. ${ }^{22}$ The hands of Jupiter Dolichenus do not, however, make the same gesture as the Sabazios hands, but instead hold all five digits straight. There are $c .17$ known examples and most of them are plain, but a few are decorated with symbols or an image of the god, in a fashion similar to those of Sabazios. ${ }^{23}$

Besides the cult of Jupiter Dolichenus, there are also a number of bronze hands from other cults, in particular those cults from the Levant. There is one bronze hand from Niha (Lebanon), that carries a small statuette of Jupiter Heliopolitanus flanked by rams, ${ }^{24}$ and there are five bronze hands from the area of Sidon..$^{25}$ Two of these carry a dedication to Theos Hypsistos. ${ }^{26}$ All of these hands hold all five digits straight. This brief overview shows that the concept of a fastened bronze hand on top of a pole was not uncommon especially among Roman soldiers, but the specific hand gesture appears to have been restricted to those of Sabazios.

All the bronze hands of Sabazios date to the Roman Imperial period and the earliest examples are from military camps, and it is plausible that the phenomenon of bronze hands surmounted on poles was diffused throughout the Roman Em-

\footnotetext{
${ }^{20}$ See e.g. Vermaseren 1983, cat. nos. 13-14, 20, 36, 43, 80, 87, 92.

${ }^{21}$ For references to iconographic and literary evidence see Lane 1989, 27,35 .

${ }^{22}$ New Pauly 4 (2004), s.v. Dolichenus, 616-617 (R. Gordon).

${ }^{23}$ Hörig 1984, 2171-2172; Hörig \& Schwertheim 1987, cat. nos. 40$41,43,53,55,70,171,181,189,262,297,351,520,595,597-599$, in addition to two eagle statuettes once attached to hands, cat. no. 191. A large hand $(87 \mathrm{~cm}$ in height) in marble was found in Dolichenum on the Aventine, Rome, cat. no. 400. Images of hands are further found on some objects, such as an altar, cat. no. 615, and a triangular relief standard which depicts a hand holding a thunderbolt, cat. no. 294 .

24 Seyrig 1954, pl. 12; Hajjar 1978, 471f., pl. 89.

${ }^{25}$ Hörig \& Schwertheim 1987, cat. nos. 44-45; Beaudouin \& Pottier $1879,264-266$

${ }^{26}$ Hörig \& Schwertheim 1987, cat. no. 44; Beaudouin \& Pottier 1879 , 265 , nos. 20-21. They are probably all from Syria. Hajjar $(1978,472)$ listed them as being from Sidon, but one of them is said to be from Asia Minor by Hörig \& Schwertheim 1987, cat. no. 44.
}

pire to a large extent by Roman soldiers. ${ }^{27}$ The bronze hand from the military camp at Dangstetten, dating to the Augustan period is the earliest-known example. ${ }^{28}$ Besides the Roman military camps the hands are most frequently found in Italy, at sites such as Pompeii. ${ }^{29}$ The distribution of the bronze hands differs somewhat from where the cult is otherwise attested..$^{30}$ It is noteworthy that no hands are known at all from Lydia, from where we have a large attestation of the cult. ${ }^{31}$ There are very few hands from the eastern part of the Mediterranean, i.e. from Greece and Asia Minor. There are only three known examples of hands from Asia Minor: a bronze hand from Antalya/Attaleia in Pamphylia, a bronze hand said to be from Caesarea in Cappadocia, ${ }^{32}$ and a third hand found on top of a bone pin, possibly a hair pin, from Gordion in Phrygia. ${ }^{33}$ The head of the pin was carved in the shape of a left hand and it was found complete except for three digits that were broken off: the thumb, and index and middle fingers (Figs. $3 \& 4$ ). These three digits were originally extended, while the outer two fingers were folded, which is the same gesture as that of the Sabazios hands. It came from a 4th-century BC context in the city mound, where it was found in a pit together with a black-glazed fish plate and a coin of Lysimachus. We are not in the position to identify it as part of the Sabazios cult, since the hand carries none of the characteristic symbols, which may be due to it being much earlier in date than the bronze hands. ${ }^{34}$ The bone pin is not unique as a few more examples with hands are known, two from Sardinia, and one from Cyprus, likewise interpreted as hair pins. ${ }^{35}$ There are further two bone pins with hands from Roman Gross-Gerau (close to Mainz in Germany) and three from French Gaul, where the fingers, however, are not preserved well enough to determine the ges-

\footnotetext{
27 Johnson 1984, 1585. Fellmann (1978, 294) suggested that the Sabazios cult at the legionary camp at Vindonissa/Dangstetten had been brought there from the legion's earlier garrison at Burnum in Dalmatia, while Lane $(1989,44)$ concluded that one of the largest groups of Sabaziosdedicants consisted of military men.

${ }^{28}$ Fellmann 1978, 286.

29 Vermaseren 1983, cat. nos. 6-33.

30 There is no evidence of hands from the Hellenistic sanctuary, supposedly dedicated to Sabazios and Demeter at Panskoye close to Chersonesos (see note 5 above), on the northern shore of the Black Sea, although there is a bronze hand of the Roman period from the area of Chersonesos (Vermaseren 1983, cat. no. 59 from Dnjepro-Petrowsk/ Chersonesos Taurica).

${ }^{31}$ Lane 1985, cat. nos. 30-42; Malay 1994, cat. nos. 62-67, 558; 1999 , cat. no. 55; von Sandern 2006, 328, no. 11. Tassignon (1998, 203, n. 81) has further collected references of inscriptions from Asia Minor.

32 Vermaseren 1983, cat. nos. 3-4.

33 Sheftel 1974, 370, 376-377. The pin measures $16.4 \mathrm{~cm}$ in length.

${ }^{34}$ The earliest securely dated bronze hand (Augustan period) is only decorated with a snake (Vermaseren 1983, cat. no. 49).

35 Vermaseren 1983, cat. nos. 34-35; Lane 1986, 199, pl. 42.3-7; 1989, 61, no. A1.
} 


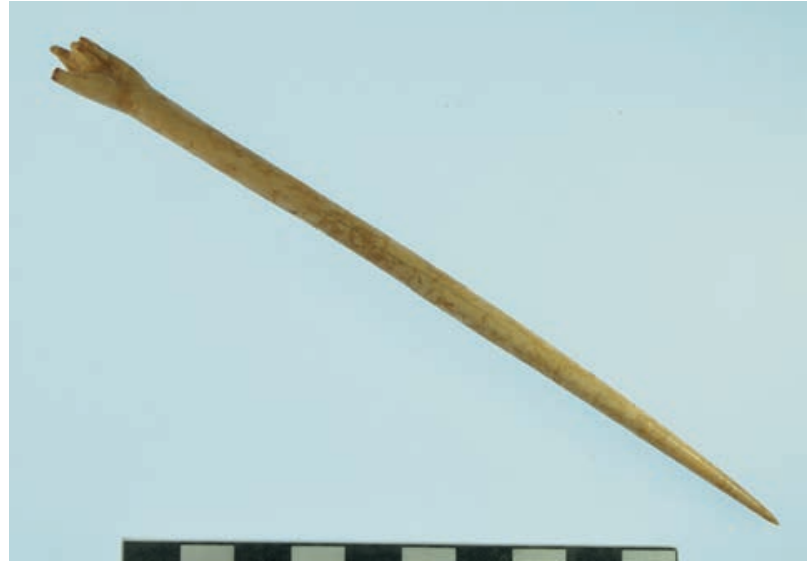

Fig. 3. Bone pin (inv. no. 2085-BI-170) from the city mound of Gordion. Preserved length $16.4 \mathrm{~cm}$. Courtesy, University of Pennsylvania Museum, Gordion Archive, image no. 2015-05439.

ture. ${ }^{36}$ It is uncertain whether these are indeed hair pins; we may consider other functions, such as styli, drawing or writing implements used on wooden tablets covered with wax. The hand on top may be seen as a more appropriate decoration for a stylos rather than a hair pin.

Be that as it may, the hands of the two pins from Sardinia are unadorned, ${ }^{37}$ while the five hands from Gaul and Germania are all encircled by snakes, which is good indication of that the latter were indeed linked to Sabazios. The hand of the Cyprus pin holds a round object, perhaps to be interpreted as a pine cone, and since a pine cone is one of the objects frequently found on the Sabazios hand (see below), it may indicate that also the Cyprus pin was associated with Sabazios. If these objects, regardless of their function, were associated with Sabazios, we may interpret them as symbols of devotion, rather than cult objects. ${ }^{38}$

The hand gesture is otherwise missing in material associated with Sabazios from Western Asia Minor, such as Lydia, from where we have some of the earliest material related to Sabazios. However, several terracotta fragments of in particular right hands were recently found in a deposit at a Hellenistic rock shrine at Priene. ${ }^{39}$ These hands are slightly larger than life size and the fingers appear to have been held in various positions. The benedictio Latina gesture cannot be confirmed for any of these hands, but the fingers of several hands were bro-

\footnotetext{
36 Hanel 1994, figs. 1-2, 6-8.

37 There are other bone pins from Sardinia that are adorned only with pine cones and no hands, see Sotgiu 1980, pls. 8-9.

${ }^{38}$ Lane $(1986,199 ; 1989,26)$ suggested that they were religious amulets perhaps worn by worshippers or priests. Hanel (1994, 65-69) described both the bronze hands and the bone pins as votive hands but also suggested the possibility that they were worn by female worshippers.

39 Filges 2015, 96-99. The terracotta hands were found together with small bronze balls.
}

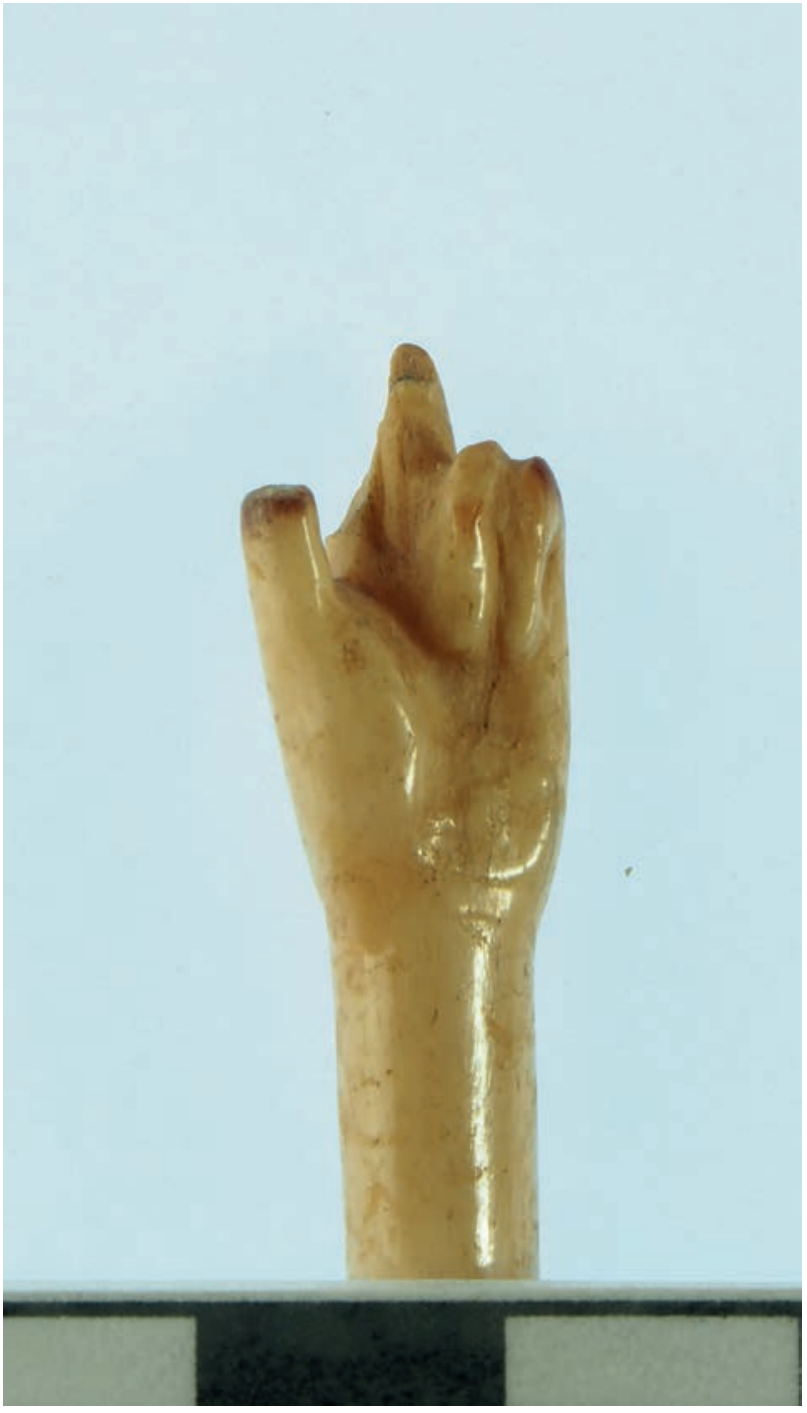

Fig. 4. The hand on top of the bone pin from Gordion. The thumb, index and middle fingers are broken off, but were held straight, while the ring and little fingers were folded. Courtesy, University of Pennsylvania Museum, Gordion Archive, image no. 2015-05440.

ken off. The shrine has on basis of the finds been identified as one of the Mother Goddess. ${ }^{40}$ Whether these hands were connected with Sabazios we do not know, but some of them were definitely not held in the benedictio Latina gesture and there is only one fragmentary hand that is a possible candidate for the Sabazios gesture, but unfortunately both the ring and little

\footnotetext{
40 Terracotta figurines of the Mother Goddess (one almost complete and heads of several others) were found below one of the small rock-cut niches (Filges 2015, 92, fig. 10). Other finds included loom weights and metal objects, and terracotta figurines of dancing young women (Filges 2015, 93-96, figs. 11-12).
} 


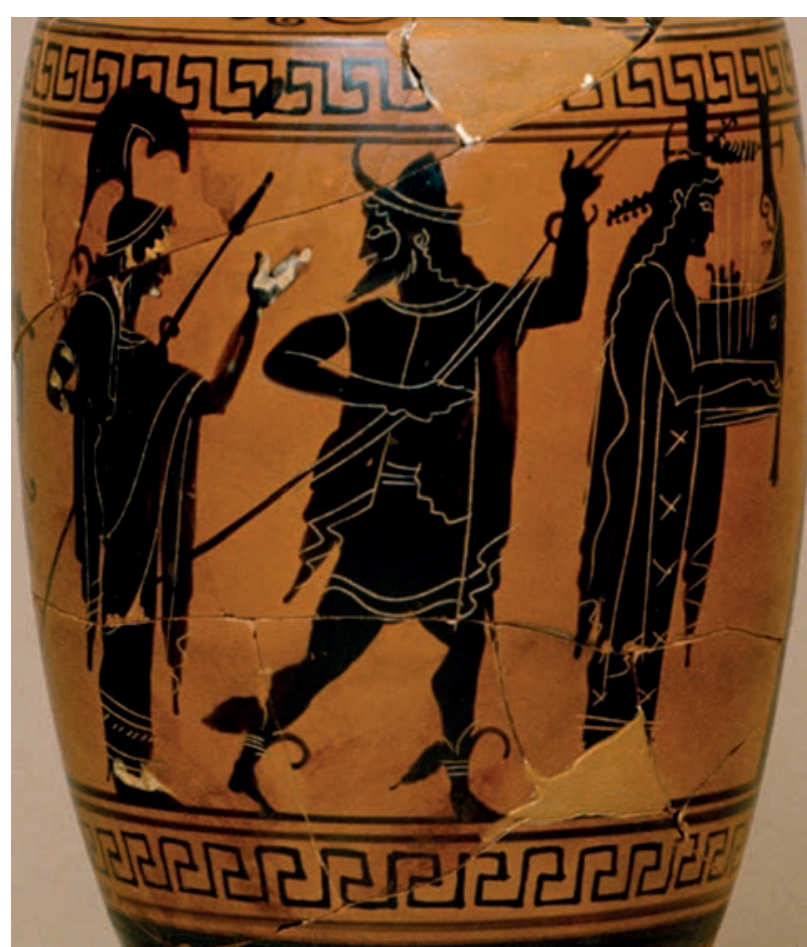

Fig. 5. The introduction of Herakles into Olympos. In front of Herakles (not seen in the image) are Athena, Hermes and Apollo. Hermes makes the benedictio Latina gesture with his left hand. Lekythos, c. 510-500 BC. Courtesy, the American School of Classical Studies at Athens: Agora Excavations, inv. no. P 24104.

fingers are broken off. ${ }^{41}$ Furthermore, none of the hands were decorated with any attached symbols. However, that feature may be later, as the earliest dated Sabazios hand from Dangstetten (see above) does not carry any other symbol than the snake. Of interest is that these hands from Priene may have filled a similar function as the Sabazios hands, as at least one of them has a hole on the lower arm that was probably used to attach it to a wooden stick. ${ }^{42}$ Further, as the fragmentary hands were all found in a shrine some form of cultic connection appears to be the most plausible interpretation.

We will now move on to discuss the hand gesture in contexts not associated with Sabazios.

\section{The hand gesture in literary sources and other contexts}

The hand gesture as such appeared much earlier in Greek vase paintings; hence the gesture was in no way restricted to

\footnotetext{
41 Filges 2015, inv. no. PR 08 Sk 4, p. 98, fig. 13.

42 Filges 2015, 97.
}

the later cult of Sabazios. Deities, mythological and human figures, are represented making the hand gesture in various contexts, and it is apparent that the gesture signified different things according to the situation. McNiven has recorded the gesture on black- and red-figured Attic pottery, and he interpreted the gesture as one of wishing good luck or averting evil, while in other scenes it was a counting gesture. ${ }^{43}$ Other scholars have demonstrated that it was also a guiding or indicative gesture. ${ }^{44}$ Hermes, for example, often made the gesture with his right hand, while he was leading a group of people (Fig. 5), ${ }^{45}$ sometimes in the role as Psychopompos ("conductor of souls'). These scenes were located in the Underworld, to where he had escorted Herakles in his endeavour to capture Kerberos. ${ }^{46} \mathrm{I}$ would like to suggest that in most of these scenes the gesture should be interpreted as one of guiding or instructing. Other deities or mythological figures represented making the gesture are, for example, Athena, Hephaistos, and satyrs or meanads, but these scenes are less common; Hermes is by far the deity most frequently associated with the gesture. ${ }^{47}$ The

\footnotetext{
43 McNiven 1982, 50-51, no. D45C/D23E, 191.

44 Both Bogen (1969, 5-6) and Neumann (1965, 17-18) have interpreted the gesture as a "deiktische Geste", i.e. as a pointing gesture, from Greek $\delta \varepsilon i \kappa v v \mu$ (show, make known, explain etc., see e.g. Hdt 4.150). However, when Neumann $(1965,84)$ referred to the gesture in a cultic context, such as Sabazios, he wrote that its meaning is uncertain.

${ }^{45}$ See e.g. a black-figured lekythos from Athenian agora (inv. no. P24104, $B A P D$ no. 7837 [here Fig. 5]), a black-figured hydria from Vulci (Vatican Museum inv. no. 420, Albizzati 1942, 190-192, pl. 64). In some examples he may be interpreted as a guide or instructor even if he is not walking in front of the others, see e.g., a black-figured krater (British Museum, London, inv. no. 1948.10-15.1, $A B V$ 108.8, BADP no. 310154), a blackfigured amphora (Museum of Fine Arts, Boston, inv. no. 01.8059; $A B V$ 667; BADP 306438); a black-figured amphora (Royal Ontario Museum, Toronto, inv. no. 919.5.141; $A B V$ 259.21; $B A D P$ no. 302253); a blackfigured hydria (British Museum, London, inv. no. B334; $A B V$ 356.71; $B A D P$ no. 302066); a black-figured amphora from Vulci (Antikensammlung, Munich; $A B V 321 ; B A D P$ no. 301686); a black-figured amphora from Tarquinia (Museo Nazionale, Tarquinia, inv. no. 681; BADP no. 13894); a red-figured amphora from Vulci (Musée de Louvre, Paris, inv. no. G1; $B A P D$ no. 200002).

${ }^{46}$ E.g. a black-figured amphora from Tarquinia (Schlossmuseum, Gotha, inv. no. AHV31; BAPD no. 12584), a black-figured amphora (Collezione Costantini, Fiesole; BAPD no. 6835), an Apulian amphora (Museo Nazionale, Tarent, inv. no. 76.010; RVAp II 763.293; BADP no 9036824); other scenes with Hermes in the Underworld are especially found on Hellenistic Apulian vases, see e.g. a hydria (Museum für Kunst und Gewerbe, Hamburg inv. no. 1982/4, RVAp 871, 57a; LIMC IV [1988], 382, s.v. Hades, no. 89 [R. Lindner]), an amphora (British Museum, London, inv. no. F332; RVAp II 733,45; LIMC IV [1988], 387 s.v. Hades, no. 149|R. Lindner]).

47 For Athena see e.g. a black-figured krater (Musée du Louvre, Paris, inv. no. Camp. 11281; CVA Musée du Louvre 8, pl. 181.2 [France 12, pl. 854]); for Hephaistos, see a black-figured pyxis (Musée de Louvre, Paris, inv. no. CA616; $A B V$ 58.122; $B A D P$ no. 300499), for a satyr see e.g. a black-figured kylix (Museo Archeologico Nazionale, Naples, inv. no. H2773; $B A D P$ no. 14134). For other examples of Hermes not mentioned in notes above, see a black-figured amphora from Vulci (Antiken-
} 
gesture is in later periods (Hellenistic and Roman Imperial times) often associated with speech or conversation, ${ }^{48}$ but a few examples may be interpreted as indicating speech in 6th century BC black-figured pottery. ${ }^{49}$ However, the gesture indicating speech is far more common on red-figured Apulian vases. Various figures are represented making the gesture, such as Hades seated next to Persephone in the Underworld (Fig. 6)..$^{50}$ Hermes on Apulian vases is represented making the gesture both as an escorter to the Underworld, ${ }^{51}$ and during conversations. ${ }^{52}$ During the Hellenistic and Roman periods the gesture could be used both for guiding and speech, as Hermes is seen making the gesture in both these positions on Apulian vases.

The gesture is also known from later profane contexts, where it indicated speech, especially among actors. ${ }^{53}$ The specific gesture is mentioned in two or three written sources. Quintilian (Inst. 11.3.92-104, c. AD 95) listed various gestures performed by a Roman orator, and some scholars are of the opinion that the benedictio Latina is not among those, while Richter argues that four variations of the gesture are listed. ${ }^{54}$ All the gestures listed by Quintilian are speech gestures and he did not elaborate much regarding the use of them, so even if this gesture is indeed described it would only confirm

sammlung, Munich, inv. no. 1562; $B A D P$ no. 1160), a black-figured amphora from Vulci (Martin von Wagner Museum, Würzburg University, inv. no. L192; $A B V$ 259.23; $B A D P$ no. 302255); a black-figured lekythos from Vulci (National Museum, Copenhagen, inv. no. B102; $B A D P$ no. 10683); a black-figured amphora (Musée Communale, Boulogne inv. no. 78; $A B V 277.17 ; B A D P$ no. 320179).

48 See Richter 2003 for an examination of the gesture during the Roman period. The gesture was later adopted by the Early Christians in their iconography of Christ and his disciples and L'Orange (1953, 171-197, esp. 171-175, figs. 120-123) has demonstrated that the benedictio Latina gesture originally indicated the spoken word.

49 See e.g. a black-figured amphora from Vulci where a man with open mouth makes the gesture in front of his face while looking at the man behind him (De Young Memorial Museum, San Francisco, inv. no. 243.24874; $A B V$ 367.92; $B A P D$ no. 302087)

50 For Hades, see e.g. an amphora (Museo Nazionale, Tarent, inv. no. 76.010; RVAp II 763.293; BAPD no. 9036824); a krater (The Spurlock Museum, University of Illinois, inv. no. 82.6.1; RVAp Suppl. 1, 152.23a; LIMC IV [1988], 386 s.v. Hades, no. 134 [R. Lindner][here Fig. 6]), an amphora (Hermitage Museum, St Petersburg, inv. no. 1701; RVAp II 523.225; LIMC IV [1988], 387 s.v. Hades, no. 156 [R. Lindner]); for female figure, perhaps Persephone see e.g. a krater (RVAp II 864.21); for other male figure, see e.g. a krater (Allard Pierson, Amsterdam, inv. no. 2586; RVAp II 501.67; LIMC IV [1988], 385 s.v. Hades, no. 128 [R. Lindner]).

51 Amphora from Museo Nazionale, Tarent, inv. no. 76.010 (RVAp II 763.293; BAPD no. 9036824).

${ }^{52}$ See e.g. a krater (Museo Nazionale Jatta, Ruvo inv. no. J 434; RVAp II, 865.24; LIMC V [1990], 362 s.v. Hermes, no. 900 [G. Siebert]).

${ }^{53}$ L'Orange 1953, 172-175, figs. 124-126. See also Richter 2003, esp. 98-102, figs. $27-28$.

54 See e.g. Aldrete 1999, 63 with n. 44. The four gestures are, according to Richter $(2003,24,28-30)$ nos. 4, 5, 8 and 9 in Quintilian's list.

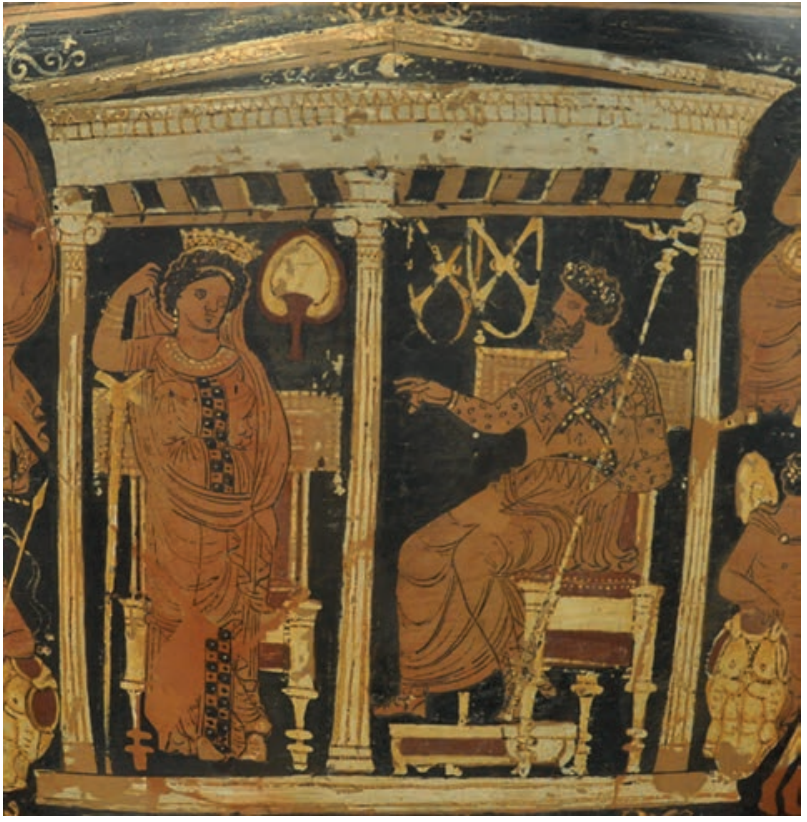

Fig. 6. Persephone and Hades in the Underworld. Hades makes the benedictio Latina gesture with his right hand. Apulian volute krater, c. 320 $B C$. Courtesy of The Spurlock Museum, University of Illinois at UrbanaChampaign, inv. no. 82.6.1.

that the gesture was connected with speech. The second source is Apuleius (Met. 2.34, c. AD 160) who described in detail the sign Thelyphron made to signal for attention before his speech began, but Apuleius also added that two fingers were folded for good luck. A much later source, Fulgentius (Virgiliana continentia 143,5 th/6th century AD), wrote that this gesture is made by the orator before his speech and L'Orange has demonstrated that the gesture is connected with teaching through speech. Christ is, for example, always holding a scroll or book in his left hand and his right hand is raised making the gesture, while his disciples are listening in front of him. Other teachers are depicted in corresponding manners. We may note, however, that the gesture later changed meaning in the Christian world and became one of blessing, ${ }^{55}$ where the three extended fingers are explained to symbolize the Trinity.

Let us now turn back to Sabazios, and what the gesture may have signifed in this cult. As mentioned above is Hermes the most common companion of Sabazios and he is also frequently represented on the bronze hands in various forms. On eleven or possibly twelve hands there is a small bust of Hermes wearing a winged petasus; more often (in 22 cases) there is an image of only the caduceus/kerykeion (herald's staff) (Fig. 7). ${ }^{56}$ It is

\footnotetext{
55 Richter 2003, 151-152.

56 A bust of Hermes is found on the following hands: Vermaseren 1983, cat. nos. $25,38,47,62,67,70,73,84,88-89,96$ and probably no. 92 . A kerykeion is found on the following hands, Vermaseren 1983, cat. nos. 1,
} 


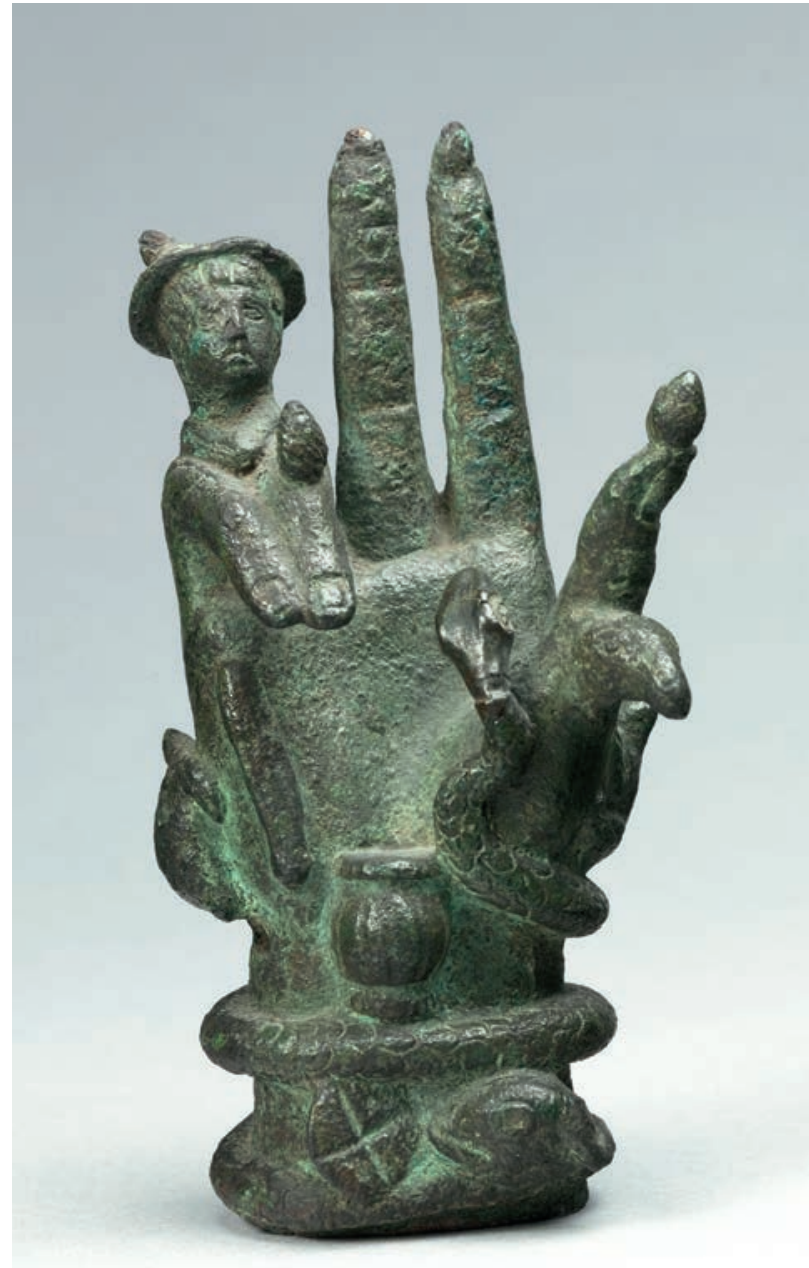

Fig. 7. Bronze hand of Sabazios with bust of Hermes. Musée du Louvre, inv. no. Br. 836. Height $12.2 \mathrm{~cm}$, 3rd century AD. Photocredits: photo (c) RMN-Grand Palais (Musée du Louvre) / Hervé Lewandowski.

significant that there is a link between the gesture and Hermes both in the earlier Greek vase paintings and on the Sabazios hands. It is hardly a coincidence in my opinion, and I would like to suggest that Hermes was closely associated with Sabazios because of his role as Psychopompos. At least by the Hellenistic period, the gesture seems to have signified speech, and was a suitable gesture to signal the instructions or secrets learned when

$3,9,13-15,17,25,29,31,45,52,57,59,66-67,70,73,75,89,92,96$. The kerykeion or Hermes is also often found on objects, other than the hands, such as a stele from Lydia (Lane 1985, cat. no. 41), five bronze tablets (Lane 1985, cat. nos. 79a, 80-82, 85), a wall painting in Rome (Lane 1985, cat. no. 65), and votive gifts in the shape of caducei from Vindonessa (Fellmann 1978, pl. 109.6). A caduceus is also depicted on a bronze tablet from Serbia, plausibly associated with Sabazios (Lane 1985, cat. no. D2, p. 45).

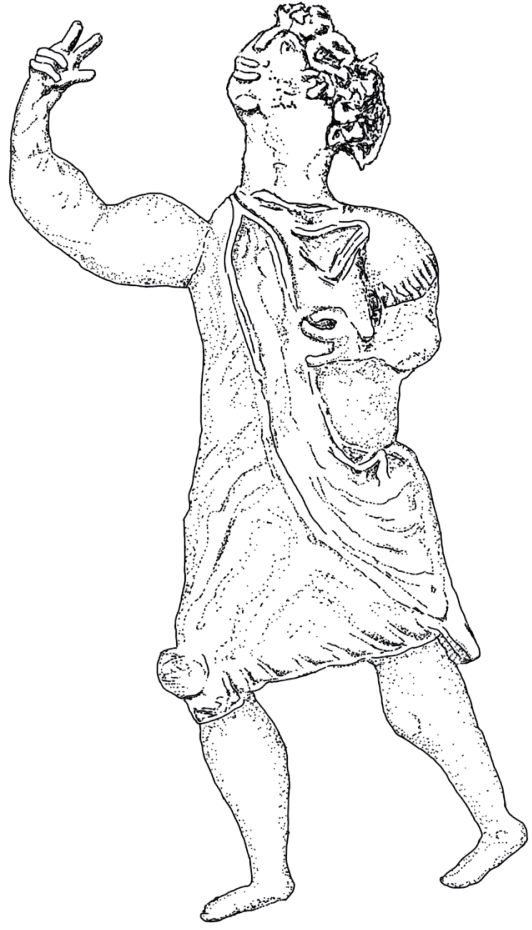

Fig. 8. Detail of krater from the Mithraeum in Mainz. The mystagogue makes the benedictio Latina gesture with his right hand. Exhibited as loan in the Archäologischen Museum Frankfurt am Main. Preserved height of the vessel is $39 \mathrm{~cm}$. Drawing by the author after published photograph, Huld-Zetsche 2008, pl. 65, figure 3, scale 1:1.

being initiated. The bronze hands may therefore be associated with the Sabazian mysteries, and they have also been interpreted as evidence of the mysteries, although the gesture itself was described as one of blessing. ${ }^{57}$ I would rather like to suggest that the gesture was adopted as a symbol of the inititation into the mysteries of Sabazios, an event that involved a mystagogue, who acted as a teacher or instructor. The mystagogue guided the mystos through the initiation process, i.e. the mystagogue acted in a position similar to that of Hermes, and especially in his role as Psychopompos. That Hermes also played this role in the Sabazios cult is explicitly demonstrated in wall paintings in a Roman tomb, where Hermes/Mercury is seen leading the deceased wife of a Sabazios priest into the Underworld. ${ }^{58}$ Let us now discuss a few examples where the gesture may be associated with other mystery cults as well.

The first example is a 2nd-century (AD 100-125) krater from the Mithraeum of Mainz in Germany (Fig. 8). ${ }^{59}$ It is ded-

\footnotetext{
57 von Ristow 1967/1968, 109.

58 Oesterley 1935, 151-156, fig. 12; Lane 1985, cat. no. 65; 1989, 13. The tomb is dated to the $3 \mathrm{rd}$ century AD.

59 Beck 2000, 147-148, with n. 12, pl. 13; Huld-Zetsche 2008, 77-79, 99-108, with references to earlier literature and interpretations.
} 


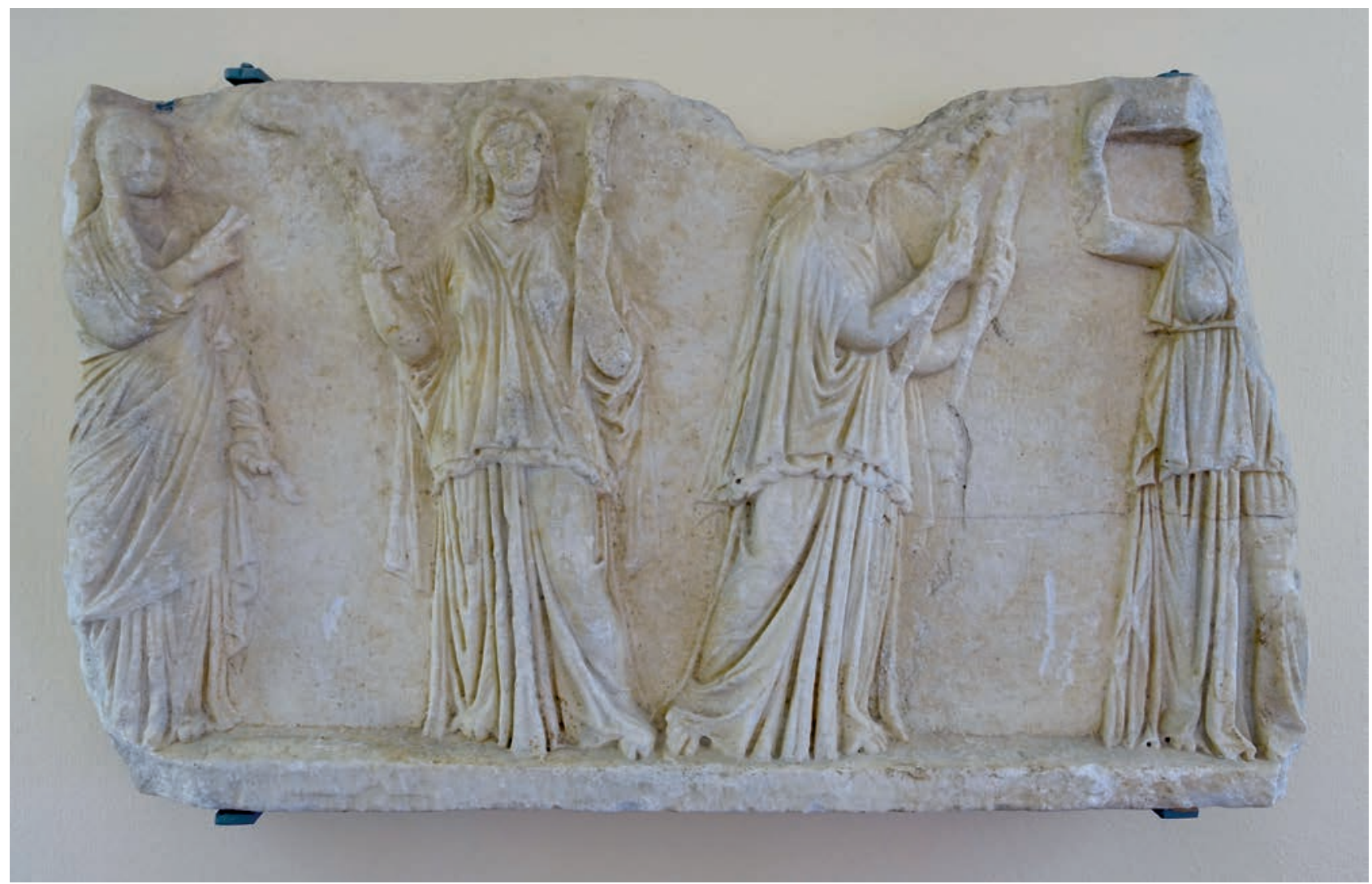

Fig. 9. Two parts of a marble relieflikely from Halicarnassos are preserved in two different museums. This is the part in the Martin von Wagner Museum in Wirzburg, inv. no. H 4794. The woman on the far left makes the benedictio Latina gesture with her right hand. By Daderot (Public domain or CCO), from Wikimedia Commons.

icated to Mithras through an inscription, and there are seven moulded figures around the body and one of them is holding up his right hand in the benedictio Latina gesture. Several suggestions have been made concerning the iconography and Roger Beck has convincingly argued that the scene depicts human participants engaged in rituals of initiation. ${ }^{60}$ The scene has three figures, a seated archer, a smaller naked man, and the gesturing man who is both walking and speaking, indicated by his open mouth. The archer has been identified as the initiator, the Father who acts as Mithras. The naked figure in the middle is the initiand, and the third figure is the mystagogue, who both guides and reveals the mysteries to the initiand. In other words the gesture is used by the mystagogue in his role as guide or teacher.

A second example is an incompletely preserved Hellenistic relief that depicts two women making the benedictio Latina gesture (Fig. 9). The relief is likely from Halicarnassos origi-

${ }^{60}$ Beck 2000, 147-154. Also Horn (1994, 25-28) who published the vessel recognized that the scene with the gesturing man was depicting a ritual of initiation. nally, but the two joining parts of the marble relief are today unfortunately kept in different museums. ${ }^{61}$ The left end of the relief is intact but it is uncertain how much of the relief is missing. Six women are represented, three on the left side are united by a ribbon or band they all grasp. The first two women of this group are seen in profile, making the benedictio Latina gesture with their right hands, while grasping the ribbon with their left hands. These two women lead the last and third woman, who is seen en face, grasping the ribbon with her left hand while raising her right hand in what is a interpreted as a praying gesture, ${ }^{62}$ towards another group of three women on the right side. Two women of this second group carry torches, while the partially preserved third woman holds a large rather flat basket, plausibly a kiste, on her head with her right hand. Only her right arm and hand are preserved, but she proba-

\footnotetext{
${ }^{61}$ Möbius 1962, 282-289. Two parts of the relief are preserved, one part in the Martin von Wagner Museum in Würzburg, inv. no. H 4794, and one part in the National Museum in Athens, inv. no. 1291.

${ }^{62}$ Möbius 1962, 284, with n. 5.
} 


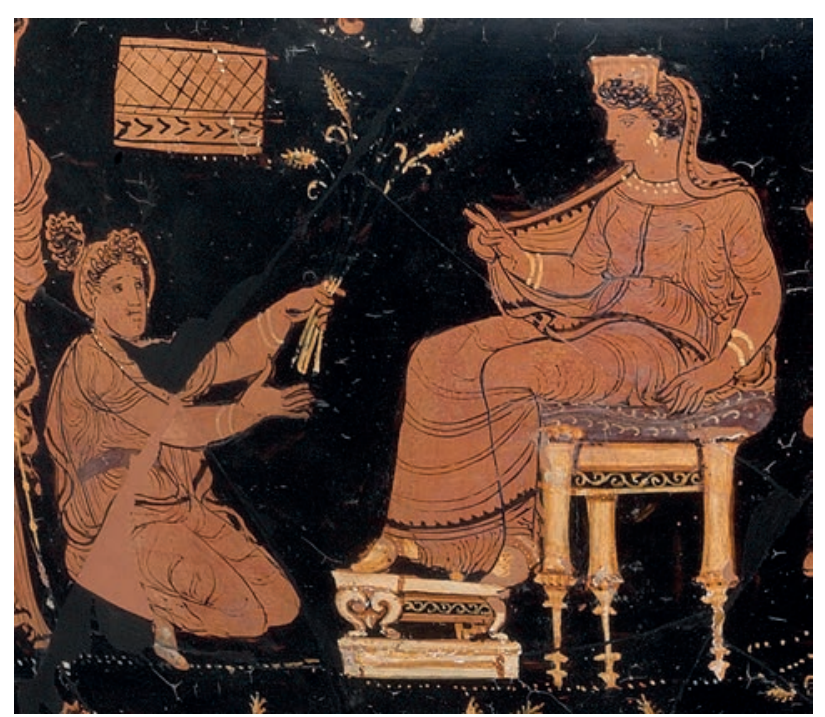

Fig. 10. Demeter makes the benedictio Latina gesture with her right hand while seated on a throne, as Metaneira kneels in front of her. Apulian hydria, c. 360/350 BC. Courtesy, Antikensammlung, Staatlische Museen zu Berlin-Preussischer Kulturbesitz, inv. no. 1984.46.

bly held the basket with both hands. ${ }^{63}$ It has been suggested that the women of the second group represent priestesses of Demeter engaged in cult rituals, and Hans Möbius suggested it might be a representation of the Thesmophoria, ${ }^{64}$ which is possible. However, considering that the person on the very left apparently is led by the other two women, which is clarified by the ribbon she is grasping, we may also consider it to be a scene associated with inititation.

A third example is found on an Apulian hydria, where the Eleusinian myth is represented (Fig. 10). Demeter makes the gesture with her right hand while she is looking at a woman kneeling in front of her. The kneeling woman has been interpreted as Metaneira, as she is seen presenting Demeter with some wheat stems. The scene depicted is probably the one where Demeter has been invited to the house of King Keleus in Eleusis and Demeter is offered a seat and she is explaining to Metaneira how to prepare the kykeon, a beverage consumed in the Eleusinian rituals, and according to Christian authors was the passage "I drank the kykeon", included in the secret symbola or passwords. ${ }^{65}$ Hence, the scene with Demeter instructing Metaneira may be interpreted as a visual reference of the initiation into the mysteries. To conclude, these three ex-

\footnotetext{
${ }^{63}$ Möbius 1962, 284.

${ }^{64}$ Möbius 1962, 284-285.

${ }^{65}$ Clem. Alex. Protr. 2.21.2; Arnob. 5.26. "I fasted, I drank the kykeon, I took from the kiste (chest); having done my task, I placed in the kalathos (basket), and from the kalathos into the kiste." Clem. Alex. Protr. 2.21.2 (translation modified from Loeb, ed. G.W. Butterworth, Cambridge MA 1919).
}

amples have to various extent served to demonstrate that the gesture was used in connection with initiation into mysteries.

Before I continue to discuss the symbols on the bronze hands, the reliefs of the so-called Dacian or Thracian Horseman, of which many are from areas of Roman military presence, should be commented upon here. These are representations of horsemen, either making the benedictio Latina gesture or holding a javelin in their right hands, while riding at full gallop. ${ }^{66}$ They are usually dated to the 2 nd and 3 rd centuries $\mathrm{AD},{ }^{67}$ and often carry an inscription where the horseman is labelled as Heros; Sabazios is never mentioned. There are some iconographical parallels with the cult of Sabazios, as the horseman is often depicted in front of an altar and a tree encircled by a snake. ${ }^{68}$ These features are, however, quite generic and may be found in many other contexts.

It is uncertain how to interpret the gesture on these reliefs. The usual interpretation is that the gesture has a similar meaning to that of Sabazios. An alternative, more attractive, interpretation is that the hand gesture is rather a representation of when an ankyle (leather loop) is used when throwing a javelin. ${ }^{69}$ The index and middle fingers were inserted into the loop of the ankyle and held straight, while the ring and little fingers held the spear. ${ }^{70}$ The upraised gesticulating arms are held in identical positions to the arms of those horsemen who are about to throw a javelin. The identical position of the arms and the hand held

\footnotetext{
${ }^{66}$ Seyrig 1927, 198-219; Hampartumian 1979, 14-15. For images see Gočeva \& Oppermann 1979, cat. nos. 54, 57, 59, 61, 111-112, 164, 167 and probably nos. 3, 149, 152, 166, 180; Gočeva \& Oppermann 1981, cat. nos. 188a, 220, 223, 279, 286, 289, 302, 327, 361, 378, 394, 403, 422, 424, and probably no. 243; Gočeva \& Oppermann 1984, cat. nos. 445-446, 449, 453, 580, and probably nos. 542, 610, 632; Hampartumian 1979 , cat. nos. 5, 13, 23-24, 30, 71, 138 and probably nos. 3 , 39, 65, 123, 180; Cermanović-Kuzmanović 1982, cat. nos. 35-36, 44, 63, 81, 91, 97 and perhaps nos. 4, 46, 98; LIMC VI (1992), 1035-1036, s.v. Heros Equitans, nos. 201-213 (M. Oppermann \& H. KoukouliChrysanthaki); Tatas 2009, 74-75, cat. nos. P 20, RH 04, RH 10, RH 13. In many cases it is uncertain whether the horseman once held a spear or made the gesture, as the reliefs are in many cases both rather coarse and eroded.

${ }^{67}$ Hampartumian 1979, 24. The majority of dedicators were of Greek or Roman origin rather than being of local descent.

${ }^{68}$ One relief from Philippopolis (today Plovdiv in Bulgaria) depicts a horseman in the lower part of the relief, and a male figure, suggested to be identified as Sabazios (Tatscheva-Hitova 1978, 1222-1224, no. 16, pl. 223), in the upper register. Lane (1985, 45, cat. no. D3, pl. 40) questioned an identification as Sabazios. It is further uncertain, whether the rider makes the benedictio Latina gesture as the relief is rather rough and damaged.

69 Tatas 2009, 74 and LIMC V (1992), 1069 Heros Equitans (H. Koukouli-Chrysanthaki, V. Machaira \& P.A Pantos) mentioned it as one possible interpretation. For the use of an ankyle see: Decker 1995, 99-100; Miller 2004, 69-71.

${ }^{70}$ Miller 2004, 69-71, figs. 133-139. See e.g. the position of the fingers of an athlete preparing to throw a javelin with the help of an ankyle, on a red-figured kylix, c. 500 BC (Musée du Louvre, inv. no. F 126; ARV² 55.13; BAPD no. 200279).
} 


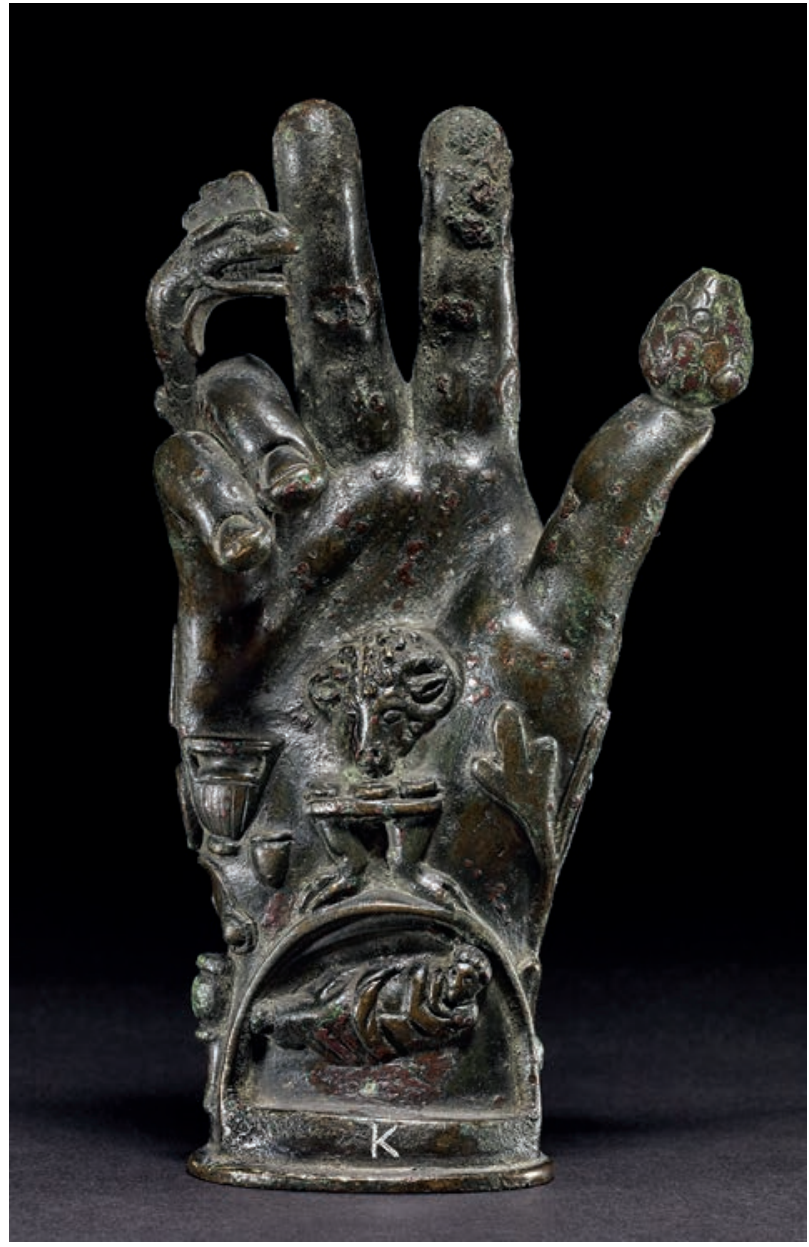

Fig. 11. The palm side of a bronze hand of Sabazios. 1st century AD. British Museum inv. no. 1824,0441.1. Length $15.24 \mathrm{~cm}$. Photocredits: () The Trustees of the British Museum

in this pose favours the interpretation that the gesture of the horseman represents the moment immediately after the javelin has been thrown rather than a gesture of speech.

\section{Symbols on the hands}

The bronze hands are often covered with symbols that to a large extent are connected with the Underworld. The most common and eye-catching of all the symbols on the Sabazios hand is the snake. The depicted snakes can be divided into two groups, one dragon-looking serpent, often with a crested head (Figs. $11 \& 12$ ),,$^{71}$ and a type of snake that appears to

\footnotetext{
${ }^{71}$ See e.g. Vermaseren 1983, cat. nos. 14, 27, 62, 70, 75.
}

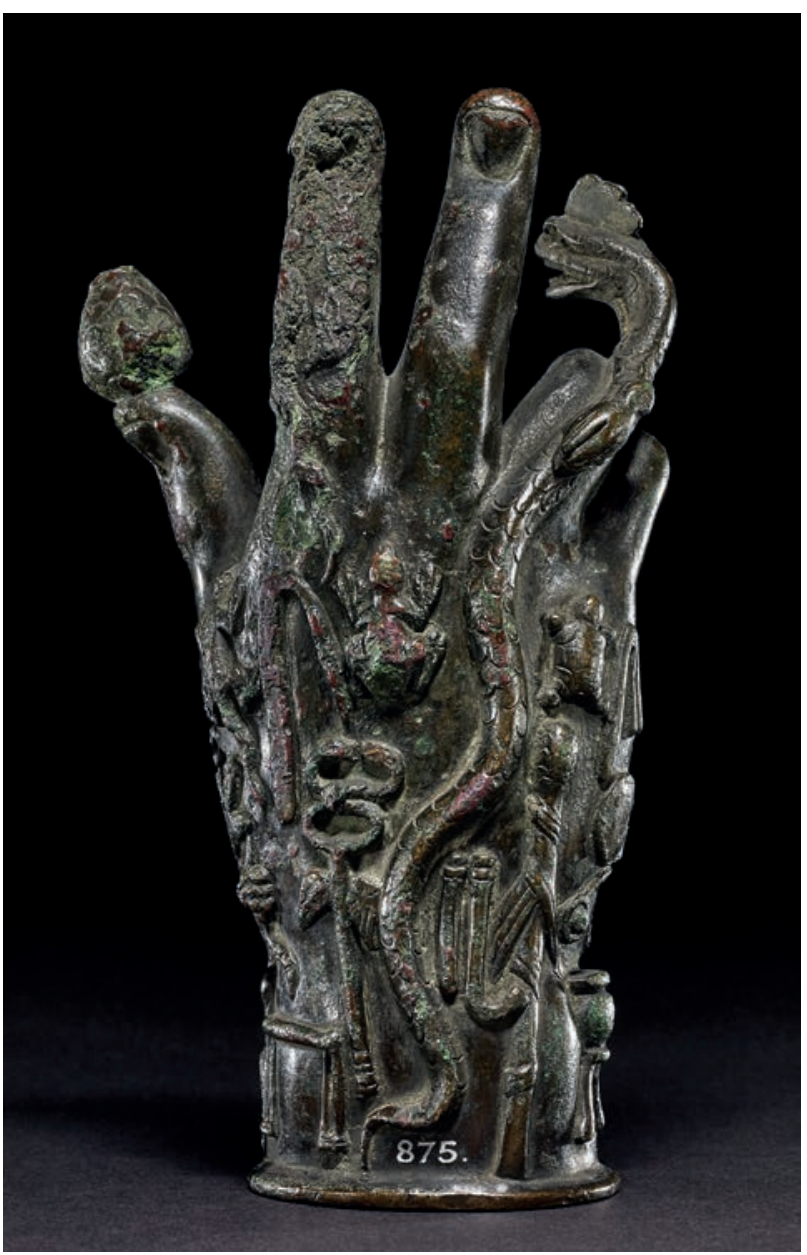

Fig. 12. The back of the bronze hand of Sabazios shown in Fig. 11. On top of the hand is a pine cone; other symbols on the hand are a crested snake, a lizard, a frog/toad, a turtle, a pair of scales, a caduceus, and flutes. 1st century AD. British Museum inv. no. 1824,0441.1. Length $15.24 \mathrm{~cm}$. Photocredits: ( ) The Trustees of the British Museum

represent a true species, but it is in my opinion not possible to determine which species they were supposed to represent. The serpent type usually dominates the hand, as it is coiled around the wrist, often with its head sticking up between the fingers. The other type of snake is represented as much smaller in size and is often found on the back of the hand. The dragon/serpent may be a reference to a mythological snake, ${ }^{72}$ while the smaller snakes plausibly are references to snakes used in cult rituals. Such snakes were probably harmless as indicated by both Theophrastus and Demosthenes who labelled the snakes of Sabazios as pareias (a reddish-brown snake that was

\footnotetext{
72 Tassignon $(1998,194-202)$ has drawn parallels between various images of the Sabazios hands and the Hittite myth of the dragon Illuyanka.
} 
also sacred to Asclepius).$^{73}$ Hence, snake-handling appears to have been important in the Sabazios cult much earlier than the preserved bronze hands, as there are references to snakes in the earliest preserved literary sources. ${ }^{74}$ The deity referred to in Demosthenes' description of the cult rituals, where the participants shouted "Evoi saboi", is generally thought to be Sabazios, and I see no reason to question this interpretation. ${ }^{75}$ Snake-handling was a central part of Demosthenes' description and the painting on a krater from Spina is a good illustration of this practice, regardless of whether the depicted deity is Sabazios, as suggested by some scholars. ${ }^{76}$ Snakes are generally connected with the Underworld and snake-handling was part of the Sabazian mysteries according to three Christian authors, who claimed that a snake was drawn over the breast and through the clothing of the initiate. ${ }^{77}$ The snake continued throughout the periods to be the most important attribute of Sabazios, as it is nearly always present, even when no other attributes are included.

Besides snakes the most common objects depicted on the hands are two other animals which also have chthonic aspects, the lizard, ${ }^{78}$ and the frog or toad (Fig. 12). ${ }^{79}$ Lane suggested that the lizard may be a symbol of death and resurrection, i.e. of renewed life..$^{80} \mathrm{~A}$ frog was in general regarded as being from the Underworld, but it also had apotropaic qualities. Frogs or

\footnotetext{
73 Theophr. Char. 16.4; Dem. De cor. 260.

74 Theophrastos (Char. 16.4, c. 320-310 BC) mentioned snakes in connection with Sabazios. Aristophanes (Vesp. 15-18, 422 BC) described in connection with Sabazios how an eagle seized in its claws a shield; this was intended to poke fun at Cleonymus who was accused of having lost his shield during a battle (RE XI [1922] s.v. 730 Kleonymos [H. Swoboda]). However, it may also be a play on words, since the word aspis (shield) also referred to an Egyptian cobra, and I found it plausible that the audience made the connection between Sabazios and snakes (LSJ, s.v. $\dot{\alpha} \sigma \pi i \zeta$, also wrote that Aristophanes made a play of the two significances of this word). Aristophanes made it even more explicit when in the next reply he refers to a well-known riddle (line 23) where the known answer was a serpent.

75 Dem. De cor. 259-260. Lane (1989, 2-3, 52-53) questioned whether the deity referred to was Sabazios, while most scholars do not.

76 Museo Nazionale, Ferrara inv. no. 2897; CVA Ferrara 1, pl. 11 (Italy 37, pl. 1655); LIMC VIII (1997), 1070 s.v. Sabazios, no. 1 (R. Gicheva).

77 Clem. Al. Protr. 2.14; Arn. Adv. nat. 5.21; Firm. Mat. Err. prof. rel. 10. See Lane 1989, 59-60 for a discussion of the texts.

78 The lizard appeared not only on numerous bronze hands (see Vermaseren 1983, cat. nos. 1-2, 7-11,13-14, 17, 25-27, 29, 31-33, 38, 42, 47, $50-52,54,56-57,59,61-62,65-68,70-73,75-76,85-86,89,91-92$, 94-96), but also on terracotta vessels and bronze reliefs (Vermaseren 1983, cat. no. H15bisa, b; Fellmann 1978, pl. 108.5 and Lane 1985, cat. no. 81$)$.

79 The frog/toad appeared also on other objects, such as reliefs (Lane 1985, cat. no. 79a), terracotta vessels (Fellmann 1978, pl. no. 108.5) and on a marble statue of Sabazios (Lane 1985, cat. no. 77). For frogs/toads on bronze hands, see Vermaseren 1983, cat. nos. 1, 2, 7-10, 13-15, 17, $25,29,31-33,38,42,50-52,57,59,61-62,66-75,84-86,89,91-92$, 94-96.

${ }^{80}$ Lane 1989, 23.
}

toads undergo metamorphosis, and in Egypt they were associated with birth because they protected against evil spirits. ${ }^{81}$ Both these animals together with the snake are, I would like to argue, symbols of the Sabazian mysteries that probably involved knowledge or experience of the Underworld.

There are a few other objects depicted on the Sabazios hands that are probably also symbols of the mysteries and the Underworld, such as pine cones, trees/branches, and ladders. A pine cone is often placed on top of a finger or held by Sabazios himself (Figs. 1, 7, $11 \& 12$ ) ${ }^{82}$ In the Roman period pine cones were sometimes depicted on tombstones, and it has been suggested that they symbolized fertility and new life, ${ }^{83}$ but pine cones were also connected with the Underworld in earlier periods. Pine cones played, for example, a role in rituals practised in the Hittite world in order to summon a deity from the Underworld, when a pine cone was placed in a pit in order to communicate with those deities. ${ }^{84}$ In Greek religion pine cones were sometimes placed along piglets in the underground "chambers" (megara) during the Thesmophoria festival of Demeter and Kore. ${ }^{85}$

A tree is a consistent feature of the Sabazios iconography and can be found on almost all types of artefacts including the bronze hands. ${ }^{86}$ In some images the Underworld is depicted beneath the roots of the tree, while the tree itself is either a pine tree or a deciduous tree, and is encircled by a snake. The previously mentioned bronze relief from Emporiae in Spain (Fig. 2), and one relief from Macedonia depict a young man appearing from the top of a tree as if he is growing out of it. ${ }^{87}$ Only the head and shoulders of the young man are seen. Lane interpreted the young man as Dionysos on the relief from Emporiae. As there is only a drawing and no photograph published, the details of his appearance are uncertain, but he appears to have some kind of leaves in his hair, while the man on

\footnotetext{
${ }^{81}$ Lane 1989, 24; New Pauly Online, s.v. Frog (C. Hünemörder).

82 A pine cone is usually also included on the reliefs (Lane 1985, cat. nos. 79a, 80-81, 83-87) and on an altar from Africa (Lane 1985, cat. no. 73). There is at least one relief where pine cones are also depicted in the tree (Lane 1985, cat. no. 85). The trees appear, however, not to be specifically pine trees, as some of them have leaves. For pine cones on bronze hands, see Vermaseren 1983, cat. nos. 1-5, 7, 13-15, 17, 25-27, $29-32,38,42,45,47,50-52,54,57,59-63,66-68,70,73-77,82-85$, $88-89,92,94,96$.

83 Cumont 1942, 219; New Pauly Online, s.v. Pine (C. Hünemörder).

${ }^{84}$ Collins 2002, 230, 237.

85 Burkert 2001, 42; Collins 2002, 237.

${ }^{86}$ A tree or branch can be found on the following hands: Vermaseren 1983 , cat. nos. 9, 13-15, 25-26, 31. A tree, sometimes encircled by a snake, is also found on material evidence other than hands, such as stelae, marble and bronze reliefs, moulds, terracotta vessels, and altars (Lane 1985, cat. nos. 25, 41-42, 78-80, 85, 87; Fellmann 1978, pls. 107, 108.5; Malay 1994, figs. 32 A \& B. A branch is found on a wallpainting in a tomb (Lane 1985, cat. no. 65).

${ }^{87}$ Lane 1985, cat. nos. 79a, 85 .
} 
the Macedonian relief wears a "Phrygian" cap on his head. I would prefer to interpret the identity of the young man to be the same on both reliefs, and if so it could hardly be Dionysos, as he is, to my knowledge, never depicted with a Phrygian cap. His identity eludes us, but we may draw a parallel with another Sabazios relief, where the head and shoulders of Helios are located immediately above a tree, although he cannot be described as emerging from the tree.$^{88}$ Even though we are not able to identify who the young men emerging from the trees are, the tree seems at least in these cases to be connected to the Underworld, since both the snake and the trunk continue below the ground level in the Macedonian image, while there is a semicircular shaped area below each tree in the Spanish relief (see further below). It is worth noting here that the Mesopotamian Weltenbaum was thought to connect the Underworld with the sky; the tree described as having its roots in the Underworld and its crown in the sky, where the sun lived. ${ }^{89}$

A ladder is depicted on two bronze hands, in addition to a krater from Pompeii, and a marble relief from Moesia Inferior. ${ }^{90}$ It has been suggested that the ladder represented the various levels of initiation, but as Lane has pointed out, the various ladders depicted have different numbers of rungs, varying between two and five. Lane limited himself to suggest that the ladder was a general symbol of aspiration of higher things for the worshipper. ${ }^{91}$

The evidence of a ladder in the Sabazios cult is quite limited, but examples are known from other cults, such as on a krater of the Mithras cult. ${ }^{92}$ Hideo Ogawa suggested that the ladder was used by Mithraists as a symbol of their salvation. ${ }^{93}$ Tassignon explained the presence of the Sabazios ladder as a means for the dragon to ascend from the Underworld, and she also drew a parallel between this ladder and the ladder on a Hittite orthostat from Alaca Höyük..$^{94}$ On the latter relief a man climbs a ladder with many rungs, while a second man waits behind for his turn. Both men are holding up their hands and making a gesture similar to the Sabazios gesture, but not identical, as the middle fingers are also folded. The impression given is that they point in the direction of the ladder, i.e. upwards. ${ }^{95}$ Next to these men is a third man holding an object, identified as a dagger, in front of his mouth. ${ }^{96}$ According

${ }^{88}$ Lane 1985 , cat. no. 80.

89 Haas 1994, 145.

90 Vermaseren 1983, cat. nos. 13-15 bis a; Lane 1985, cat. no. 78.

91 Lane 1989, 33.

92 Ogawa 1978.

93 Ogawa 1978,873

94 Tassignon 1998, 199.

95 Also the man, generally identified as the king, standing in front of the altar makes the same gesture towards the altar.

96 These men have been discussed by several scholars, and they have been suggested as depicting acrobats and a dagger-swallower, but there is no consensus of how to interpret them, see e.g. Gurney 1994; Ünal 1994 to Hittite texts both daggers and ladders were used to create a communication with the deities of the Underworld. A dagger was used to dig the pit into which a silver ladder was lowered, and sometimes clay models of daggers were also spread out close to the pit. ${ }^{97}$ It is not my intention here to discuss the interpretation of the Alaca Höyük relief, but rather limit myself to suggest that it may represent a ritual aimed at establishing contact with the Underworld.

Furthermore, a ladder to heaven is mentioned in the Hittite Kamrusepa myth. ${ }^{98}$ It would thus seem that ladders were regarded as links between Earth and the Underworld as well as between Earth and Heaven. We may note that the ladder is also present in similar concepts in other pagan cults as well as in Christianity and Judaism. ${ }^{99}$ Jacob saw in a dream angels climbing a ladder that connected Heaven with Earth (Book of Genesis 28.10-19). To conclude, the ladder depicted on Sabazios objects was most probably also a symbol of a connection between various worlds, at least between the Underworld and Earth, but perhaps also to Heaven.

A pair of scales is an attribute that appears predominantly on the hands (Fig. 12). It occurs, according to Lane, on 27 hands and three bronze plaques. ${ }^{100}$ Lane considered that the symbol should be interpreted as a scale for weighing the worshipper's merits and sins. Scales can be found in many cultures connected with the passing to the Underworld of the deceased. For example, in the Iliad Zeus used a set of scales to weigh the deceased in order to decide whether they would go to the Underworld or to Heaven. ${ }^{101}$ They were a tool to ascertain the destiny of mortals, and sets of scales were also connected with death in later periods, as they were a common symbol on Roman tombstones. ${ }^{102}$ Hence, I would like to suggest that the scales depicted on the Sabazios monuments were likewise associated with the Underworld, and indirectly with the Sabazian mysteries.

A reclining woman nursing a child represented within a semicircular area is part of the iconography of 18 bronze hands and the bronze relief from Emporiae (Figs. $2 \& 11) .{ }^{103}$ This motif is sometimes accompanied with other symbols,

and Taracha 2011, 137-138, 145-146. It is uncertain whether the man with the dagger is only holding the dagger in front of his mouth or if he is actually intending to swallow it.

${ }_{97}$ Puhvel 1984, s.v. api-; 1991, s.v. hat(t)-, hatta-, hazziya-; Collins 2002.

${ }_{98}$ Hoffner 1998,33 , no. $10, \$ 5$.

99 Leglay 1964; Ogawa 1978, esp. 864-872.

${ }^{100}$ Lane 1989, 33.

101 Il. 8.69-74, 16.658, 19.223, 22.209-10. The Homeric Hymn to Hermes (4.324) likewise mentioned the scales of judgement, which were set up before Zeus on top of Mount Olympus. For an example of a Hittite ritual, see Haas 1994, 221-222.

102 New Pauly Online, s.v. Scales (M.PU.).

103 Vermaseren 1983, cat. nos. 8, 10, 13-15, 17, 29, 33, 47, 50, 52, 59, 68, $71,75,79,86,92$; Lane 1985 , cat. no. 85 . 
such as large birds and reptiles. The semicircular area is interpreted by Lane as a cave, ${ }^{104}$ but the area is void of cave-like features, such as rocks. The area is always semicircular and always located just above the wrist of the bronze hands. These features are helpful for our interpretation.

The bronze relief from Emporiae is the only one that places the semicircular areas into an iconographic context (Fig. 2). There are two semicircular areas on the relief, each one located immediately below a tree, i.e. these areas should be interpreted as being in the Underworld, which is further confirmed by a line indicating the ground on which Sabazios and three small juglets stand.

How should we then interpret the nursing woman in the Underworld? Lane suggested that this image may refer to the mythological birth of Sabazios. ${ }^{105}$ His birth is only mentioned in later sources; Diodorus Siculus wrote that Persephone gave birth to him, with Zeus being the father. ${ }^{106}$ Persephone is of course a suitable candidate for the Underworld, and there are other sources that refer to Zeus who in the form of a snake seduced Persephone. This event is for example told by the Christian writers when referring to rituals of the Sabazian mysteries. ${ }^{107}$ It is therefore possible that the scene of a woman nursing a child in the Underworld was meant to be a reference to Persephone or whoever was regarded as his mother. The nursing of infants connected either to Demeter at Eleusis or Persephone in the Underworld occur twice. Demeter acted as a nurse of the infant Demophoon, the son of King Keleon at Eleusis, while according to another mythological narrative, Persephone took care of the infant Adonis in the Underworld. There is, however, no such information regarding Sabazios. ${ }^{108}$ Let us therefore approach this problem with a broader perspective in mind.

According to Christian authors, a sacred boy Brimo was said to have been born as an essential part of the initiation rituals at Eleusis, ${ }^{109}$ and the birth of a child was also mentioned as part of the mysteries of Isis. ${ }^{110}$ Parallels with Hittite religion have been noted above, and let us again consider Hittite beliefs and rituals associated with the Underworld. The

\footnotetext{
104 Lane 1989, 26.

105 Lane 1989, 26.

106 Diod. Sic. 4.4.1. Strabo (10.3.15) wrote that Sabazios belonged to the Phrygian group of deities, and in a way was the child of the Mother, as he also transmitted the rites of Dionysos. According to Mnaseas of Patara (3rd century BC) Sabazios was the son of Dionysos (FHG 3.155, preserved in the Suda, s.v. ¿áßol). See also Hymn. Orph. 48, 49.

107 Clem. Al. Protr. 2.14; Arn. Adv. nat. 5.20-21.

108 Ps-Apollodorus, Bibl. 1.184-185. The cult of Sabazios is connected with Adonis in an early story by Aristophanes (Lys. 386-397) who seems to make no differentiation between the two cults and their rituals. Adonis is also mentioned by Apuleius (Met. 8.25) in connection with Sabazios. 109 Hippol. Haer. 5.8.40; See also Bremmer 2014, 9, 14.

${ }^{110}$ Mesomedes, Hymn 5. See also Bremmer 2014, 12.
}

Sun Goddess of Earth was the main deity in the Underworld, dwelling in a palace there. She may be compared with Persephone who was regarded as Queen of the Underworld, although Hades was the ruler, but the concept of a palace in the Underworld is similar. ${ }^{111}$ Besides the Sun Goddess of Earth, other chthonic deities such as goddesses of birth and fate were also inhabitants of the Underworld. ${ }^{12}$ Birth and death seem to have been intimately linked to each other, and on the basis of Hittite royal funerary rites, scholars have suggested that death was thought of as a second birth or rebirth, ${ }^{113}$ a theme which is also expressed in connection with some ritual initiations of the mystery cults. ${ }^{114}$ We may note that cremation was an essential part of the Hittite royal ritual, and has a parallel in the highlights of the Eleusinian mysteries, with the infant Brimo born amid fire. ${ }^{115}$ It is, however, not the purpose of this article to explore this link any further, but rather, based on earlier Anatolian beliefs, to demonstrate an alternative interpretation of the "woman and child" scene of the bronze hands. It may be a purely mythological scene, but it may also be a reference to cosmological beliefs or initiation rituals of the Sabazian mysteries.

Besides the symbols discussed above there are also others on the bronze hand, of which there is no apparent connection to the Underworld, but rather to rituals that may have been part of the mysteries, such as the whip, which is perhaps a reference to flagellation. ${ }^{116}$ Other common objects are kraters or similar vessels, bread or cakes, musical instruments or noise makers, and the head of a ram (Figs. 7, $11 \& 12)$.

\section{The adoption of the gesture into the cult of Sabazios}

It has been suggested by earlier scholars that the hand gesture of Sabazios originally came from the Semitic area and was introduced into the cult of Sabazios by Jews who had settled in Anatolia. ${ }^{117}$ Antiochos III had resettled around 2,000 Jewish

\footnotetext{
111 Collins 2002; Haas 1995, 2030.

112 Collins 2002, 225.

113 Beckman 1983, 237; van den Hout 1994, 43; Kozlova 2017, 28-29.

114 See e.g. Apul. Met. 11.24, see also Bremmer 2014, 124; Meyer 1987, 5,8 .

${ }_{115}$ Haas 1995, 2023; Hippol. Haer. 5.8.40. Fire is also mentioned in connection with the mysteries of Isis, see Bremmer 2014, 14.

116 According to Lane $(1989,33)$ a whip is represented on 19 hands and one plaque, and he made a reference to the flagellation scene in the Villa of the Mysteries at Pompeii. Another reference to a flagellation scene connected with initiation is the earlier-mentioned krater of the Mithras cult (see note 59 above), where one figure holds a whip. Flagellation was also practised by Galloi, the followers of Kybele.

117 Cumont 1906, 70; Oesterley 1935, 140; Macrea 1959, 329; Lozovan 1968,219 . The gesture of a raised right hand and arm is discussed
} 
families from Babylonia in Lydia and Phrygia around 200 BC, and there were for example groups of Jews at Apamea/Kelainai, Laodikeia, and Akmonia. ${ }^{118}$ There are, however, no indications that the hand gesture was introduced into the Sabazios cult by the Jewish population. As I have demonstrated above the gesture existed as such much earlier in Greece and Apulia as well as Anatolia. Furthermore, the hand gesture is never connected with Sabazios in the preserved material from Lydia or in those areas where the Jews were resettled. We may further note that the gesture to my knowledge is not documented in any Syrian image, which is yet another argument against a Syrian origin. ${ }^{119}$ The concept of using images of hands as cult objects may, however, still have influenced the Sabazios cult. It remains a possibility that Roman soldiers became acquainted with such cultic objects in Syria or south-east Anatolia, after the area had become a Roman province in 64 BC when Pompey defeated the Armenian king Tigranes in the Third Mithridatic War. Regardless of where the Roman soldiers picked up the phenomenon of bronze hands surmounted on staffs, it is probably due to them that it spread so quickly throughout the Mediterranean area.

Whether the gesture played any role in the mysteries of Sabazios prior to the Roman period, we do not know, but the gesture as such was plausibly used in various mystery cults during the Hellenistic period, as indicated by the material discussed above. By the Roman Imperial period the gesture had become part of the established iconography of Sabazios.

\section{Conclusions}

The so-called benedictio Latina gesture was not exclusive to the Sabazios cult, but had become a significant feature of the cult not later than the Augustan period. One function, perhaps out of several, was to attach the bronze hands to staffs, which were likely displayed in processions. This practice was probably introduced into the cult of Sabazios towards the very end of the Hellenistic period or beginning of the Roman Empire, as indicated by the earliest finds of such hands. Roman soldiers undoubtedly contributed to the distribution of this practice around the Mediterranean, and they may have picked up this feature after south-east Asia Minor and Syria had became part of the Roman republic in 64 BC. Speaking

by L'Orange (1953, 139-170, esp. 157) who suggested a Semitic origin. 118 Cumont 1906, 63; Oesterley 1935, 126. The small statue of Sabazios from Çavdarlı has unfortunately both hands missing, but it is the left arm and not the right arm that is raised. He may originally have held a staff with a hand attached at the top in his left hand (Lane 1985, cat. no. 77).

119 An argument put forward by Nilsson $\left(G G R^{3}, 658, \mathrm{n}\right.$. 3). There is one bronze hand of Sabazios that is said to be from Aleppo (Vermaseren 1983, cat. no. 74). in favour of such a theory is the fact that two other cults, Jupiter Dolichenus and Jupiter Heliopolitanus, where the same concept of bronze hands existed, originated from these areas. We may, however, note that recent excavations have proved that terracotta models of hands which were likely also to have been displayed on staffs in religious contexts already existed in Western Asia Minor during the Hellenistic period.

The gesture itself signified the spoken word or logos but was also used as an instructive gesture, and the gesture was therefore suitable for Hermes, who is the figure most frequently depicted making the gesture on Greek vase paintings. Hermes was also closely associated with Sabazios, and frequently represented on the bronze hands, together with many other symbols, such as snakes, frogs/toads, lizards, serpents, ladders and sets of scales, all of which may be associated with the Underworld, and the Sabazian mysteries. There is evidence that the gesture was used during the Hellenistic period in connection with mystery cults, to signify the knowledge or instructions given by the mystagogue during the initiations. The gesture of the Sabazios hands signified the knowledge acquired during the initiation to the Sabazios mysteries. The bronze hands may have functioned as tokens of the initiation into the Sabazios mysteries, and were likely to have been displayed in processions.

It was not my intention to examine a possible Anatolian background of the cult in this paper, but it turned out to be inevitable to touch upon earlier, especially Hittite, beliefs and rituals connected with the Underworld. These examinations further strengthened the case of an Anatolian background of the Sabazios cult.

SUSANNE BERNDT

Department of Archaeology and Classical Studies

Stockholm University

106 91 Stockholm

Sweden

susanne.berndt@antiken.su.se

\section{Bibliography}

Albizzati, C. 1942. Vasi antichi dipinti del Vaticano 7, Rome.

Aldrete, G.S. 1999. Gestures and acclamations in ancient Rome, Baltimore \& London.

Beaudouin, M. \& E. Pottier 1879. 'Collection de M. Péretié: Inscriptions', $B C H$ 3:1, 257-271. https://doi.org/10.3406/bch.1879.4390

Beck, R. 2000. 'Ritual, myth, doctrine, and initiations in the mysteries of Mithras: New evidence from a cult vessel', JRS 90, 145-180. https://doi.org/10.1017/s0075435800031373 
Beckman, G. 1983. Hittite birth rituals (Studien zu den Boğazköy-Texten, 29), Wiesbaden.

Blinkenberg, C. 1904. Archaeologische Studien, Leipzig.

Bodinger, M. 2002. 'Deux problèmes d'histoire des religions au monde antique: I. Le dieu Sabazios et le Judaïsme', Archaeus 6, 121-139.

Bogen, K. 1969. Gesten in Begrüssungsszenen auf attischen Vasen, Bonn.

Bremmer, J.N. 2014. Initiation into the mysteries of the ancient world, Berlin. https://doi.org/10.1515/9783110299557

Briant, P. 1998. 'Droaphernès et la statue de Sardes', in Achaemenid History 11. Studies in Persian History: Essays in memory of David M. Lewis, eds. M. Brosius \& A. Kuhrt, Leiden, 205-226.

Burkert, W. 2001. Savage energies. Lessons of myth and ritual in ancient Greece, Chicago \& London.

Cermanović-Kuzmanović, A. 1982. Corpus cultus equitis Thracii (CCET) V. Monumenta intra fines Ingoslaviae reperta (ÉPRO, 74), Leiden. https://doi.org/10.1163/9789004296435

Collins, B.J. 2002. 'Necromancy, fertility and the dark earth: The use of ritual pits in Hittite cult', in Magic and ritual in the ancient world, eds. P. Mirecki \& M. Meyer, Leiden, 224-241. https://doi.org/10.1163/9789047400400_013

Cumont, F. 1906. 'Les mystères de Sabazius et le judaïsme', CRAI 50:1, 63-79. https://doi.org/10.3406/crai.1906.71756

Cumont, F. 1942. Recherches sur le symbolisme funéraire des Romains, Paris.

Decker, W. 1995. Sport in der griechischen Antike. Vom minoischen Wettkampf bis zu den Olympischen Spielen, München.

Dusinberre, E.R.M. 2003. Aspects of empire in Achaemenid Sardis, Cambridge.

Edmonds, J.M. 1957. The fragments of Attic comedy: after Meineke, Bergk, and Kock 1, Leiden.

Eisele, T. 1909-1915. 'Sabazios', in Ausfürliches Lexikon der griechischen und römischen Mythologie 4, ed. W.H. Roscher, Leipzig, 232-264.
Fellmann, R. 1978. 'Belege zum Sabazioskult im frühkaiserzeitlichen Legionslager von Vindonissa', in Studien zur Religion und Kultur Kleinasiens: Festschrift für Karl Dörner zum 65. Geburtstag am 28. Februar 1976. I (ÉPRO, 66), eds. S. Şahin, E. Schwertheim \& J. Wagner, Leiden, 284-294. https://doi.org/10.1163/9789004295377_014

Fellmann, R. 1981. 'Der Sabazios-Kult', in Die Orientalischen Religionen im Römerreich, ed. M.J. Vermaseren, Leiden, 316-340. https://doi.org/10.1163/9789004295711_013

Filges, A. 2015. 'Ein Felsheiligtum im Stadtgebiet von Priene', in Natur-Kult-Raum. Akten des internationalen Kolloquiums Paris-Lodron-Universität Salzburg, 20.-22. Jänner 2012 (Österreichisches Archäologisches Institut Sonderschriften, 51), eds. K. Sporn, S. Ladstätter \& M. Kerschner, Vienna, 81-109.

Fol, A. 1998. 'Pontic interactions: The cult of Sabazios', in The Greek colonisation of the Black Sea area, ed. G.R. Tsetskhladze, Stuttgart, 79-84.

Gočeva, Z. \& M. Oppermann 1979. Corpus cultus equitis Thracii (CCET) I. Monumenta Orae Ponti Euxini Bulgariae (ÉPRO, 74), Leiden. https://doi.org/10.1163/9789004295513

Gočeva, Z. \& M. Oppermann 1981. Corpus cultus equitis Thracii (CCET) II.1. Monumenta inter Danubium et Haemum reperta (ÉPRO, 74), Leiden. https://doi.org/10.1163/9789004296442

Gočeva, Z. \& M. Oppermann 1984. Corpus cultus equitis Thracii (CCET) II.2. Monumenta inter Danubium et Haemum reperta (ÉPRO, 74), Leiden. https://doi.org/10.1163/9789004295537

Gurney, O.R. 1994. 'The ladder-men at Alaca Höyük', AnatSt 44, 219-220. https://doi.org/10.2307/3642993

Haas, V. 1994. Geschichte der hethitischen Religion, Leiden. https://doi.org/10.1163/9789004293946

Haas, V. 1995. 'Death and the afterlife in Hittite thought', in Civilizations of the ancient Near East 3, ed. J.M. Sasson, New York, 2021-2030.

Hajjar, Y. 1978. 'À propos d'une main de Sabazios au Louvre', in Hommages à Maarten J. Vermaseren 1 (ÉPRO, 68), eds. M.B. de Boer \& T.A. Edridge, Leiden, 455-472. https://doi.org/10.1163/9789004295421_030 
Hampartumian, N. 1979. Corpus cultus equitis Thracii (CCET) IV (ÉPRO, 74), Leiden. https://doi.org/10.1163/9789004295520

Hanel, N. 1994. 'Beinnadeln mit Sabazios-Händen und Kybelebüste. Zeugnisse kleinasiatischer Mysterienreligionen im römischen Gross-Gerau', ArchKorrBl 24, 65-71.

Hannestad, L., V.F. Stolba \& A.N. Ščeglov, eds. 2002. Panskoye I. The monumental building U6, Aarhus.

Hoffner, H.A. 1998. Hittite myths, Atlanta.

Hörig, M. 1984. 'Jupiter Dolichenus', in $A N R W$ II 17:4, Berlin \& New York, 2136-2179.

Hörig, M. \& E. Schwertheim 1987. Corpus cultus Iovis Dolicheni (ÉPRO, 106), Leiden. https://doi.org/10.1163/9789004295742

Horn, H.G. 1994. 'Das Mainzer Mithrasgefäss', Mainzer Archäologische Zeitschrift 1, 21-66.

Huld-Zetsche, I. 2008. Der Mithraskult in Mainz und das Mithräum am Ballplatz, Mainz.

Johnson, S.E. 1984. 'The present state of Sabazios research', in $A N R W$ II, eds. G. Sotgiu \& M. de'Spagnolis, 17:3, 1583-1613, Berlin \& New York.

Kozlova, E.E. 2017. Maternal grief in the Hebrew Bible, Oxford. https://doi.org/10.1093/oso/9780198796879.001.0001

Lane, E.N. 1980. 'Towards a definition of the iconography of Sabazius', Numen 27, 9-33. https://doi.org/10.1163/156852780x00134

Lane, E.N. 1985. Corpus Cultus Iovis Sabazii (CCIS) II. The other monuments and literary evidence (ÉPRO, 100), Leiden. https://doi.org/10.1163/9789004296527

Lane, E.N. 1986. 'Sabazius-artifacts from Cyprus', RDAC, 197-201.

Lane, E.N. 1989. Corpus Cultus Iovis Sabazii (CCIS) III. Conclusions (ÉPRO, 100), Leiden. https://doi.org/10.1163/9789004296534

Leglay, M. 1964. 'Le symbolisme de l'échelle sur les stèles africaines dédiées à Saturne', Latomus 23, 213-246.

L'Orange, H.P. 1953. Studies on the iconography of cosmic kingship in the ancient world, Oslo.

Lozovan, E. 1968. 'Dacia Sacra', History of Religions 7 , 209-243. https://doi.org/10.1086/462563
Macrea, E. 1959. 'Le culte de Sabazius en Dacie', Dacia N.S. 3, 325-339.

Malay, H. 1994. Greek and Latin inscriptions in the Manisa museum (DenkschrWien, 237), Vienna.

Malay, H. 1999. Researches in Lydia, Mysia and Aiolis (DenkschrWien, 279), Vienna.

McNiven T. 1982. Gestures in Attic vase painting: Use and meaning, 550-450 BC, Ph.D. thesis, University of Michigan.

Meyer, M.W., ed. 1987. The ancient mysteries. A sourcebook of sacred texts, Philadelphia.

Miller, S.G. 2004. Ancient Greek athletics, New Haven.

Möbius, H. 1962. 'Hellenistischer Fries in Würzburg und Athen', AM 77, 282-289.

Neumann, G. 1965. Gesten und Gebärden in der griechischen Kunst, Berlin.

Oesterley, W.O.E. 1935. 'The cult of Sabazios: A study in religious syncretism', in The labyrinth, ed. S.H. Hooke, London, 115-158.

Ogawa, H. 1978. 'Mithraic ladder symbols and the Friedberg Crater', in Hommages à Maarten J. Vermaseren 2, eds. M.B. Boer \& T.A Edridge, Leiden, 854-873. https://doi.org/10.1163/9789004295438_021

Popova, R. 2007. 'The cult of Sabazios in the North Black Sea-via Thrace?', in Thrace in the Graeco-Roman world. Proceedings of the 10th International Congress of Thracology, Komotini-Alexandroupolis 18-23 October 2005, ed. A. Iakovidou, Athens, 492-499.

Puhvel, J. 1984. Hittite etymological dictionary 1, Berlin. https://doi.org/10.1515/9783110823370

Puhvel, J. 1991. Hittite etymological dictionary 3, Berlin. https://doi.org/10.1515/9783110848106

Richter, T. 2003. Der Zweifingergestus in der römischen Kunst (Frankfurter archäologische Schriften, 2), Möhnesee.

Robert, L. 1975. 'Une nouvelle inscription grecque de Sardes: Règlement de l'autorité perse relatif à un culte de Zeus', CRAI 119:2, 306-330. https://doi.org/10.3406/crai.1975.13135

Roller, L.E. 2001. 'The Anatolian cult of Sabazios', in Ancient journeys: A festschrift in honor of Eugene Numa Lane, ed. C. Callaway. http://www.stoa.org/hopper/text.jsp?doc=Stoa: text:2001.01.0008 
Roller, L.E. 2013. 'Sabazios', in The encyclopedia of ancient history 11, eds. R.S. Bagnall, K. Brodersen, C.B. Champion, A. Erskine \& S.R. Huebner, Oxford, 5987-5988. https://doi.org/10.1002/9781444338386.wbeah17401

Seyrig, H. 1927. 'Quatre cultes de Thasos', BCH 51:1, 178-233. https://doi.org/10.3406/bch.1927.5050

Seyrig, H. 1954. 'Antiquités syriennes' Syria 31:1, 68-98. https://doi.org/10.3406/syria.1954.5062

Sheftel, P.A. 1974. The ivory, bone and shell objects from Gordion from the campaigns of 1950 through 1973, Ph.D. thesis, University of Pennsylvania.

Sotgiu, G. 1980. 'Per la diffusione del culto di Sabazio. Testaminianze dalla Sardegna', in G. Sotgiu \& M. de’Spagnolis, Nuovi ritrovamenti (ÉPRO, 86), Leiden, 1-26. https://doi.org/10.1163/9789004295667

Takács, S.A. 2001. 'Sabazius', Neue Pauly 10, 1180-1182. https://doi.org/10.1163/2214-8647_bnp_e1026280

Taracha, P. 2011. 'The iconographic program of the sculptures of Alacahöyük', JANER 11:2, 132-147. https://doi.org/10.1163/156921211x603922

Tassignon, I. 1998. 'Sabazios dans les panthéons des cités d'Asie Mineure', Kernos 11, 189-208. https://doi.org/10.4000/kernos.1227

Tatas, A.E. 2009. Die figürlichen Grabstelen im römischen Thessaloniki, M.A. thesis, Ruprecht-Karls-Universität Heidelberg.
Tatscheva-Hitova, M. 1978. 'Wesenszüge des Sabazioskultes in Moesia inferior und Thracia', in Hommages à Maarten J. Vermaseren 3, eds. M.B. de Boer \& T.A. Edridge, Leiden, 1217-1230. https://doi.org/10.1163/9789004295452_018

Ünal, A. 1994. 'The textual illustration of the "jester scene" on the sculptures of Alaca Höyük', AnatSt 44, 207-218. https://doi.org/10.2307/3642992

van den Hout, T.P.J. 1994. 'Death as a privilege. The Hittite royal funerary ritual', in Hidden futures. Death and immortality in Ancient Egypt, Anatolia, the Classical, Biblical and Arabic-Islamic world, eds. J.M. Bremmer, T.P.J. van den Hout \& R. Peters, Amsterdam, 37-75.

Vermaseren, M.J. 1983. Corpus Cultus Iovis Sabazii (CCIS) I. The hands (ÉPRO, 100), Leiden. https://doi.org/10.1163/9789004296510

von der Osten, H.H. 1953. 'Eine neue Sabazios-Statuette', Orientalia Suecana 2, 29-35.

von Ristow, G. 1967/1968. 'Zur Eschatologie auf Denkmälern synkretistisch-orientalischer Mysterienkulte in Köln', Kölner Jahrbuch für Vor- und Frühgeschichte 9, 107-111.

von Sandern, F. 2006. 'Anhang: Katalog der Inschriften', in Blaundos. Berichte zur Erforschung einer Kleinstadt im lydisch-phrygischen Grenzgebiet (IstForsch, 48), ed. A. Filges, Tübingen, 321-350.

Widengren, G. 1961. 'Die Sabaziosmysterien', in Religionsgeschichte des Orients in der Zeit der Weltreligionen, ed. B. Spuler (Handbuch der Orientalistik, 1.8.2) Leiden, 62-64. 